\title{
UBERLÂNDIA: DA BOCA DO SERTÃO À CIDADE JARDIM
}

\author{
Beatriz Ribeiro Soares \\ Profa. Dra. do Dep. de Geografia - UFU
}

Há setenta anos, era São Pedro de Uberabinha. Hoje é a maravilhosa Uberlândia. Uberlândia do arranha-céu Tubal Vilela. Uberlândia do negro tapete de asfalto, das lambretas desfilando à noite, à luz de milhares de luminosos a gaz néon colorindo a vida da cidade tentacular. Uberlândia de gente apressada, de gente trabalhando, dos operários, dos comerciários que fazem rush às 11 horas da manhã às seis da tarde. Uberlândia, enfim esta grandeza, este borborinho humano, esta maravilha de cidade se agita, sofre, ri, chora, de acordo com as conveniências. Mas, acima disso é Uberlândia grande e altaneira, a metrópole triangulina, nossa terra, nosso orgulho. (CORREIO DE UBERLÂNDIA, 30/08/58: 01)

RESUMO: Este artigo retrata as transformações espaciais da cidade de Uberlândia, sobretudo aquelas decorrentes da acumulação do capital comercial. A cidade cresceu e desenvolveuse até os anos 50 sob o signo do comércio e à medida que se expandiam os mercados, modificavam-se as estruturas econômicas, acirrava-se o discurso progressista das elites locais e, assim sendo, era preciso reformular a forma urbana. As mudanças almejavam o progresso e a modernidade e fundamentavam-se na expansão das relações capitalistas e no embelezamento da paisagem urbana.

Palavras Chaves: cidade, paisagem urbana, transformações sócio/espaciais.

ABSTRACT: This paper shows the spacial transformation of Uberlandia City, specially those decurrents from commercial capitalist accumulation. The city grew up and develloped up to the fifty's under the sign of business and as the market expanded, the economical structures changed, the progressive ideas of local upper classes got raised and it was necessary to change the urban format. The changes aimed to progress and modernization and they were based on the expansion of capitalist relations and in the "beauty" of the urban landscape.

Key Words: city, urban landscape, spacial transformations.

\section{INTRODUÇÃO}

A cidade, enquanto locus da criação, do progresso, da invenção, da liberdade, sempre exerceu atração, fascínio, principalmente pela força de seu caráter simbólico. Ela simboliza o poder do homem em modificar o meio ambiente; representa a fonte de invenção de novas idéias políticas, sociais, científicas e culturais. Nesse sentido, a cidade, que também possibilita acúmulo de riquezas e melhoria de qualidade de vida para seus usuários, é a expressão das tradições e culturas.

PECHMAN (1994:04), estudando o significado da cidade, mostra que ela é

(...) palco de ensaio do surgimento de novos personagens sociais, da gestação de uma nova sensibilidade, da elaboração de novas formas de 
sociabilidade, da construção de novos sistemas de saber e técnicas de poder, a cidade se apresenta como um enigma a ser decifrado.

A materialidade da cidade deve expressar os símbolos de seu povo, sua visão de mundo, sua história, enfim o cenário da vida econômica e social, onde possa haver uma constante integração entre o individual e o coletivo, a casa e a rua, as praças e as áreas de trabalho e lazer.

Presente e passado convivem, criando nas contínuas e diversas aproximações e justaposições, uma nova linguagem, extremamente articulada. Ao percorrer uma cidade se tem a percepção visual do fluir do tempo. O olhar reconhece nas coisas, nas imagens, nas construções, nas ordens e nas medidas do espaço, a sua função. Todas as cidades tem seu código, uma vez conhecido um, em qualquer outro espaço urbano o forasteiro encontrará fragmentos de sua história. (CHIAVARI \& CARVALHO, 1991:84).

A cidade, refletindo um modo de viver, de pensar e de sentir das pessoas, produzindo idéias, valores, conhecimentos tem sua imagem impregnada de memórias e significações, que se materializam na paisagem urbana e reproduzem diversos momentos do processo de produção espacial.

Quando observamos a paisagem urbana, sua realidade é, para nós, onipresente e inevitável; por onde quer que olhemos, percebemos suas ruas e praças, edifícios, seus monumentos, seus conjuntos habitacionais, seus shopping-centers, sinais elétricos, entre outros. No entanto, ela se apresenta para nós banalizada, porque é componente de nosso cotidiano urbano.

As paisagens modernas merecem ser compreendidas e apreciadas. As mudanças que se têm operado no último século, tanto em caráter como em escala, têm sido enormes. Quer se goste delas ou não, para a grande maioria de nós são o contexto da vida quotidiana e, portanto, merecem algo de nossa atenção crítica. São também, segundo praticamente qualquer padrão, uma das grandes realizações construtivas da idade moderna. (RELPH, 1992:12).

As paisagens urbanas são a expressão de valores e capacidades da sociedade, e, por sua imagem, por sua durabilidade, constituem e constituirão um legado de seu tempo para o futuro. Este cenário, que hoje faz parte do nosso cotidiano, é fruto das influências tecnológicas e sociais que ocorreram no passado.

Portanto, a paisagem urbana concretiza os diversos momentos do desenvolvimento das relações sociais, e, sendo assim, ela é histórica e social, produto do trabalho dos homens em sociedade. As diversas formas de ocupação do solo, os espaços abertos e os espaços construídos colocam-se aos nossos olhos, enquanto atividades produzidas pelo trabalho dos homens entre si e com a natureza, segundo o processo de desenvolvimento das forças produtivas. De acordo com GOMES (1994:23), a cidade como ambiente construído, como necessidade histórica é resultado da imaginação e do trabalho coletivo do homem que desafia a natureza.

O objetivo desse trabalho é retratar as transformações sócio/espaciais da cidade de Uberlândia, sobretudo aquelas decorrentes da acumulação do capital comercial, visto que a cidade cresceu e desenvolveu-se até os anos 50 sob o signo do comércio e à medida que se expandiam os mercados; modificavam-se as estruturas econômicas; acirrava-se o discurso progressista das elites locais com relação às reformulações da forma urbana. Essas 
mudanças almejavam o progresso e a modernidade e fundamentavam-se na expansão das relações capitalistas e no embelezamento da paisagem urbana.

\section{UBERLÂNDIA: DA BOCA DO SERTÃO AO ENTREPOSTO COMERCIAL: AS RELAÇÕES ECONÔMICAS}

Uberlândia, até o início do século XX, era considerada como a Boca do Sertão, o fim de parada do Centro Oeste brasileiro, porque se localizava no limite extremo do sertão mineiro. Nesse período, as principais cidades do Triângulo Mineiro eram Araguari e Uberaba, que acumulavam riquezas, bens e serviços, sendo que Uberlândia, apesar de servida pela Estrada de Ferro Mogiana, desde 1895, era apenas uma pequena estação no percurso da referida estrada, conforme podemos constatar na FIGURA 01.

Entretanto, ocorreram mudanças nas relações entre essas cidades, sobretudo, a partir de 1913, quando foram construídas estradas de rodagem pela Companhia Mineira de Autoviação Intermunicipal e a ponte Afonso Pena que, conjuntamente, interligavam Goiás e Mato Grosso ao Triângulo Mineiro, particularmente a Uberlândia.

Figura 1: Esquema das linhas ferroviárias (São Paulo - Minas Gerais - Goiás)

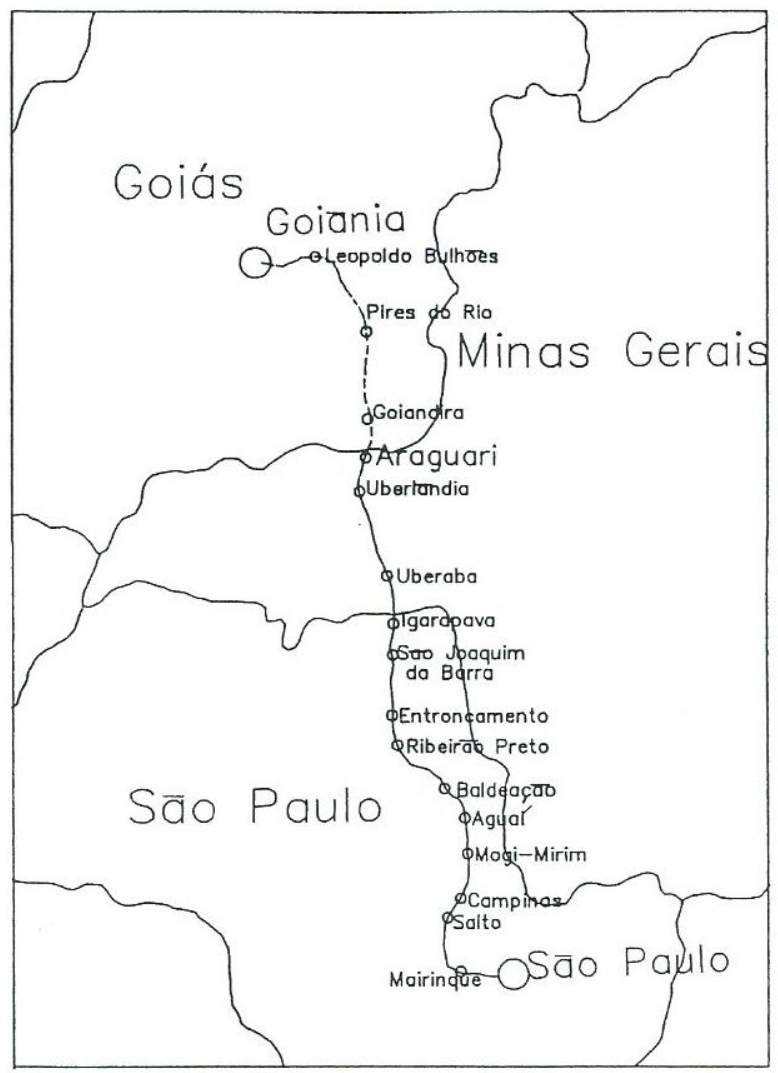

Fonte: 
Evidentemente, esses foram os fatores que fizeram com que a cidade se expandisse e conquistasse um lugar de destaque no cenário estadual e nacional. $A$ expansão da Cia Mineira de Autoviação Intermunicipal estabeleceu um entroncamento rodoferroviário estratégico, pois canalizou para Uberlândia a produção do Sudoeste Goiano, intensificando assim o comércio, com o surgimento de estabelecimentos comerciais atacadistas. Isto gerou para Uberlândia a situação de pólo comercial e foi a semente que deu origem à prosperidade que Uberlândia tem hoje. (CORREIO DE UBERLÂNDIA, 31.08.87:02).

Podemos afirmar que Uberlândia cresceu e desenvolveu-se sob o signo das estradas de rodagem. E, nesse processo, é preciso destacar o papel exercido pelos comerciantes locais, pelos motoristas de caminhão, conhecidos, então, como chauffeurs, e pelas transportadoras de cargas, que diversificaram a atividade comercial da cidade, a partir dos anos 30 , devido à intensificação das relações entre os Estados de Mato Grosso e Goiás, fundamentalmente.

No começo dos anos 30, o atacado era comandado por Rezende \& Cia, Custódio Pereira, Teixeira Costa e alguns outros que vendiam para $o$ Triângulo Mineiro e Sudoeste Goiano pelo sistema de contas correntes. Pelos meados da década Nêgo Amâncio e outros motoristas começaram a chegar até Mato Grosso, puxando para Uberlândia a compra dos varejistas daquela zona. No fim dos anos 30 começa o deslanche vigoroso do atacado de Uberlândia. (CORREIO DE UBERLÂNDIA, 31/08/88:25).
A comercialização e a distribuição de mercadorias, naquele período, era feita a partir dos produtos industrializados provenientes de São Paulo, que chegavam à cidade pela Estrada de Ferro Mogiana. Daí em diante eram transportados para as outras praças por caminhões, em condições muito precárias, uma vez que as estradas eram de péssima qualidade, principalmente nos períodos mais chuvosos, além de existir o entrave natural dos rios e ribeirões.

\section{Eram os motoristas denominados} pelos historiadores locais novos bandeirantes do sertão do Centro Oeste, encarregados de transportar as mercadorias, e, por vezes levavam-nas sem terem recebido o pagamento, só o tomando no retorno à cidade. O papel desempenhado pelo comércio e, particularmente, por esses motoristas de caminhão, foi importantíssimo no crescimento de Uberlândia, sobretudo porque eles abriram e expandiram as fronteiras do Centro-Oeste, geraram riquezas para a cidade, além de terem podido incorporar novos hábitos e costumes aos moradores daquelas áreas. ${ }^{1}$

A penetração das rodovias acenou com possibilidades mais intensas às energias humanas do rincão. O chofer fez-se sertanista. Afrontou as jornadas em caminhos bons e maos. A situação geográfica de Uberlândia oferecia vantagens iniludíveis ao intercâmbio do comércio. Os homens do volante começaram no vai-vem de permutas de produção. Recebiam aqui, da via férrea levavam para as longínquas paragens, as cargas preciosas. Fizeram da localidade um vértice da irradiação dos negócios. Atraíram interesses de outras praças goianas e matogrossenses,

Segundo os registros escritos, vários tipos de alimentos foram incorporados à dieta dos moradores do Centro Oeste pelos "chauffers" de Uberlândia, como por exemplo as massas alimentícias. 
permitindo aos comissários facilidades ao seu progresso. $(O$ REPÓRTER, 07/11/42:01).

O sistema de autonomia dos motoristas perdurou até os anos 50 , quando as empresas passaram a comercializar seus produtos, utilizando seus próprios viajantes. Observa-se, a partir desse período, a especialização entre empresas distribuidoras na cidade, visto que no princípio e no momento de fixação de sua hegemonia, praticamente só existiam grandes armazéns de secos e molhados, que atendiam tanto os setores de material de construção, ferramentas, tecidos, armarinhos, alimentos, como derivados de petróleo. ${ }^{2}$

Esse processo, demonstrando a existência de bases comerciais sólidas, permitiu novas experiências, pois atraiu empresas para a cidade, tais como distribuidoras de combustíveis, atacadistas de tecidos, vidros, materiais de construção, entre outros.

\section{Expandiram-se os mercados,} modificaram-se as estruturas comerciais no que diz respeito ao sistema de pagamento, à criação de empresas transportadoras de carga, e assim a figura daquele motorista que vendia, recebia o pagamento e era dono do seu caminhão, foi paulatinamente desaparecendo, enquanto as empresas comerciais diversificavam-se e cresciam cada vez mais.

Com a construção de Brasília e a modernização da economia brasileira, esse processo se diversifica e intensifica cada vez mais, visto que o consumo aumenta muito e novas praças vão sendo incorporadas, fazendo com que outras empresas atacadistas sejam criadas em Uberlândia. É nesse período que os grandes atacadistas da atualidade, tais como Martins Comércio e Exportação, Armazém do Comércio ARCOM, Peixoto, começam suas atividades. ${ }^{3}$

Essas novas empresas comerciais substituíram os velhos pioneiros atacadistas de secos e molhados, que tinham a hegemonia do comércio uberlandense para o Centro Oeste, até os anos 50.

Os efeitos da construção de Brasília e das estradas que a ela convergiam, permitiram, na década de 60, a fixação de bons atacadistas estabelecidos a partir da década anterior e a definição dos novos gigantes dos secos e molhados, agora liberados de produtos paralelos assumidos por outras firmas. (CORREIO DE UBERLÂNDIA, 31/08/ 88:28).

Nessas condições, Uberlândia consolida-se no Triângulo Mineiro como um entreposto comercial, sobretudo porque não dispunha de terras apropriadas ao cultivo de grãos, e a pecuária era ainda muito atrasada, se comparada a de Uberaba. Quanto ao setor industrial, até os anos 40 muito pouco ainda tinha sido feito; o número de estabelecimentos industriais era de apenas 163 fábricas, com 1.443 operários (ÁLBUM DO TRIÂNGULO MINEIRO 1940:42), não havendo possibilidades de a cidade, em pouco tempo, transformar-se num parque de produção industrial.

\footnotetext{
2 Nesse período, são instalados os armazéns e depósitos das distribuidoras de petróleo SHELL, ESSO, TEXACO e ATLANTIC. O Rodoviário Caçula, uma grande empresa de transportes, instala-se em Uberlândia, em 1957.

3 Em 1953, iniciam-se as atividades dos Armazéns Martins, empresa atacadista que cobre atualmente $85 \%$ do território nacional, distribuindo bens de consumo não duráveis. Em 1965, duas outras empresas atacadistas iniciam suas atividades neste setor: Armazém Peixoto e Armazém do Comércio - ARCOM, que também comercializam produtos em grande parte do território nacional.
} 
Em decorrência dessas mudanças, e também pela possibilidade de perder posição na comercialização com o Mato Grosso e Goiás, visto que tinham sido instalados, em meados da década de 30 , os mercados de Goiânia e Anapólis, as elites uberlandenses chamam a atenção da população e dos políticos locais, através da imprensa, para a necessidade de diversificação do comércio e da implantação de indústrias.

\section{Urge que se consolide a riqueza do Triângulo, e esta se dará com a construção de indústrias na região, máxima em Uberlândia, que é sem dúvida uma das grandes potências triangulinas. E nesse ritmo crescente de progresso, num futuro próximo poderemos apresentar Uberlândia como sendo uma das grandes cidades industriais do Triângulo. (O REPÓRTER, 1952:02).}

Por se transformar em um entreposto comercial, acirra-se o discurso do progresso na cidade, sendo a imprensa o principal veículo dessa idéia:

Uberlândia é uma cidade privilegiada. Seu destino é crescer sempre quer do labor de sua operosa população, aliado a uma insuperável posição geográfica, resultou a mais próspera de todas as cidades do interior do Brasil. Plantada no divisor das águas do Rio Grande e Paranaíba, em região de clima incomparável, vai Uberlândia se firmando dia a dia como centro industrial, agrícola e comercial de toda vasta zona meridional do estados de Goiaz e Mato Grosso e ainda também de quase todo o Triângulo Mineiro. (CORREIO DE UBERLÂNDIA, 04/05/48:02).

Esse discurso foi ainda mais intensificado, quando houve a possibilidade de a cidade vir a ser a capital federal, em 1946, ano em que foram feitas pesquisas por estudiosos e técnicos do Governo Federal, na tentativa de encontrar uma nova área para ser instalada a futura capital, no Planalto Central.

Geograficamente, Uberlândia, satisfaz plenamente, é situada no centro do Brasil, em região de reconhecida fertilidade, é ligada ao resto do país por rodovias e estradas de ferro. Além disso, trata-se de uma cidade moderna, suficientemente credenciada pelo alto nível do progresso alcançado, a tornar-se a capital da República. Nas condições atuais, bastaria a construção de edifícios públicos e incrementar a edificação de prédios residenciais para as sedes das embaixadas e para abrigar a nova população constituída dos funcionários do Governo Federal. As vantagens seriam inumeráveis. (UBERLÂNDIA ILUSTRADA, jul./46).

\section{DA BOCA DO SERTÃOÀ CIDADE JARDIM: AS FORMAS ESPACIAIS}

Uberlândia, como grande parte das cidades brasileiras fundadas até a virada do século $X X$, desenvolveu-se espontaneamente, sem um planejamento inicial, com ruas tortuosas, casas geralmente precárias e, por vezes, improvisadas.

Até o final do século passado, era apenas uma cidade localizada na Boca do Sertão, acanhada, sem belezas naturais, e ainda, isolada dos grandes centros. Diante dessa realidade, que não se coadunava com a visão dos políticos locais, era então preciso reformulá-la, enfeitá-la .

As mudanças visavam, sobretudo, adequar a forma urbana às possibilidades de acumulação do capital, de modo que a cidade simbolizasse o progresso, indicativo das novas condições econômicas implementadas pela atividade comercial. Para atingir esse objetivo, era necessário 
criar uma nova concepção de cidade e de sociedade, pela qual seriam impostos aos seus personagens novos valores, atitudes e comportamentos, que, sem dúvida, criariam uma nova urbanidade.

Foi assim que Uberabinha renovouse em Uberlândia. Com esse surto de atividades, as casas velhas desapareceram, surgiram os palacetes, o perímetro urbano ampliou-se, formaram-se as avenidas. (O REPÓRTER, 07/11) 42:01).

Esse processo iniciou-se a partir da instalação da estação ferroviária, em 1895, no extremo norte da cidade, quando os comerciantes e moradores instalados no bairro do Fundinho começaram a se deslocar naquela direção.

Esse referencial urbano, a estação ferroviária, norteou o crescimento de Uberlândia, durante muitos anos.

Criaram-se outras projeções na sua paisagem urbana. Os tentáculos das ruas estenderam-se para cima. As casas mudaram o feitio das fachadas. Alinharam-se com maior regularidade. A estrada de ferro lá no alto da rampa, atraindo, chamando os habitantes para mais perto. Agitando novidades com a chegada dos comboios. O cerrado povoou-se. (O REPÓRTER, 02/07/44:01).

Uma cidade que almejava o progresso e a modernidade, sobretudo, porque essas mudanças expressavam e fundamentavam a expansão das relações capitalistas, não podia conviver com ruas estreitas e tortuosas, em que se misturavam cavalos, carroças, automóveis, lojas com mercadorias amontoadas, que dificultavam a circulação de pessoas, e, principalmente, enfeavam a paisagem urbana.
Era necessário, então, que se fizesse uma intervenção em sua forma urbana, que possibilitasse a sua fragmentação em áreas apropriadas ao comércio, ao lazer e à residência das populações mais ricas. Enfim, era preciso planejar seu espaço urbano.

\section{Os planejamentos urbanos} concebidos naquele período tinham como objetivo propor a reconstrução das cidades, visando solucionar os problemas urbanos existentes, mas, antes de tudo, melhorar sua aparência. Os princípios que norteavam esses projetos tinham como pressupostos os preceitos de beleza, ordem e limpeza.

As áreas urbanas deveriam, portanto, concretizar o pensamento daquela época, no qual o desenvolvimento econômico impunha o ordenamento do espaço ao nível técnico, em que seriam privilegiados o transporte urbano, programas de saneamento para a construção de redes de esgoto sanitário e outros equipamentos necessários à vida urbana, fazendo com que as cidades fossem limpas e belas, registrando o progresso da sociedade moderna (RELPH, 1992).

PECHMAN (1992:78), em seus estudos sobre a imagem urbana do Rio de Janeiro, no início do século $X X$, mostra a necessidade de reordenação do espaço nestes parâmetros: era preciso, pois, depurar a cidade, sanear o meio ambiente e eliminar fatores de feiura e sujeira. Neste sentido, o espaço público - a rua - deveria ser a expressão dos padrões de limpeza, beleza e ordem.

Nesse cenário, as aglomerações urbanas deveriam expandir-se através de avenidas largas, amplas e extensas e, se possível, seriam eliminados os caminhos estreitos e tortuosos das velhas e antigas cidades. Essas reformulações tentavam sepultar a imagem urbana antiga, tradicional, feia e desordenada.

REIS FILHO (1994), estudando as transformações das cidades, mostra que o 
plano do Barão de Haussmann, proposto para Paris, entre os anos 1850/75, e posteriormente, difundido em quase todos os países do mundo, introduziu uma nova forma de construção da paisagem urbana, a partir da reformulação do sistema viário, com largas avenidas, dotadas de arborização, que formavam os eixos diretivos, e também a implantação de edifícios padronizados.

Sob essa concepção, foi elaborado um projeto urbanístico, para Uberlândia pelo engenheiro Mellor Ferreira Amado, entre os anos 1907 e 1908, que projetou um novo traçado urbano para a cidade.

Foi esse o primeiro plano diretor de Uberlândia, e talvez o único até o momento presente implantado integralmente, conforme as orientações técnicas e urbanísticas propostas.

Estávamos ainda na era das tropas de burros, dos carros de bois e cabrioletes puxados a cavalo, daí nossa admiração aos incentivadores da nova planta urbanística, dando-nos essas largas e belas avenidas, as admiráveis ruas transversais que permitem hoje, o trânsito de automóveis, ônibus $e$ caminhões. (CORREIO DE UBERLÂNDIA, 27/02/70:06).

O projeto, que postulava a construção de uma paisagem completamente nova para a cidade, criou uma outra área central, com um conjunto de largas e extensas avenidas arborizadas e ruas transversais, que formavam um tabuleiro de xadrez.

O traçado em quadriculado, com avenidas e ruas formando ângulos retos, encontrado em várias cidades brasileiras e americanas naquele período, criou uma paisagem urbana monótona, como podemos verificar nas considerações de MARX (1980:37):

As peculiaridades destas centenas de aglomerações novas são excepcionais entre nós pela regularidade de conjunto de cada uma [...], os espigões ou chapadas acomodam ruas em tabuleiro de xadrez e uma sempre presente praça central, a da Matriz. Paisagem marcante e referência usuais no oeste paulista que conferem feição marcante e monótona, tanto aos estabelecimentos rurais como urbanos. Entre o divisor de águas ou a estrada de ferro e o fundo do vale ou o abastecimento de água, quadras regulares descem suavemente exibindo casarões que anunciam a República. Regularidade, conforma-ção arredondada, núcleo central e contorno mais nítidos são traços evidentes e exaustivamente repetidos.

A opção pelo traçado retangular foi facilitada pela estrutura física da área, com terrenos pouco inclinados, que favoreceram a expansão da cidade. Mesmo assim, posteriormente, a sua continuidade, com relação a novos lançamentos de loteamentos, não raro não foi levada em conta, o que dificultou a implantação de um sistema viário contínuo entre os bairros.

DEL GROSSI (1991:14), estudando a geomorfologia urbana de Uberlândia, constatou que

(...) a cidade desenvolveu-se ao longo do espigão entre o rio Uberabinha $e$ os pequenos afluentes da margem esquerda do rio Araguari. [...] Esta posição ao longo desse divisor, mesmo contando com várias nascentes nas suas proximidades, mostra-se como um sítio favorável ao crescimento urbano, notadamente junto ao divisor principal.

Foram então abertas cinco avenidas paralelas - Afonso Pena, Floriano Peixoto, Cipriano Del Fávero, João Pinheiro e Cesário Alvim -, na direção Norte/Sul, que se 
tornaram, a partir daquele período, as principais vias públicas da cidade, e ainda

oito ruas transversais ${ }^{4}$, conforme pode ser observado na FIGURA 02 e FOTO 01.

Figura 2: Planta da cidade de Uberabinha - 1927 - Escala 1:5.000 (Aprox.) - SETEMBRO MCMXXVII

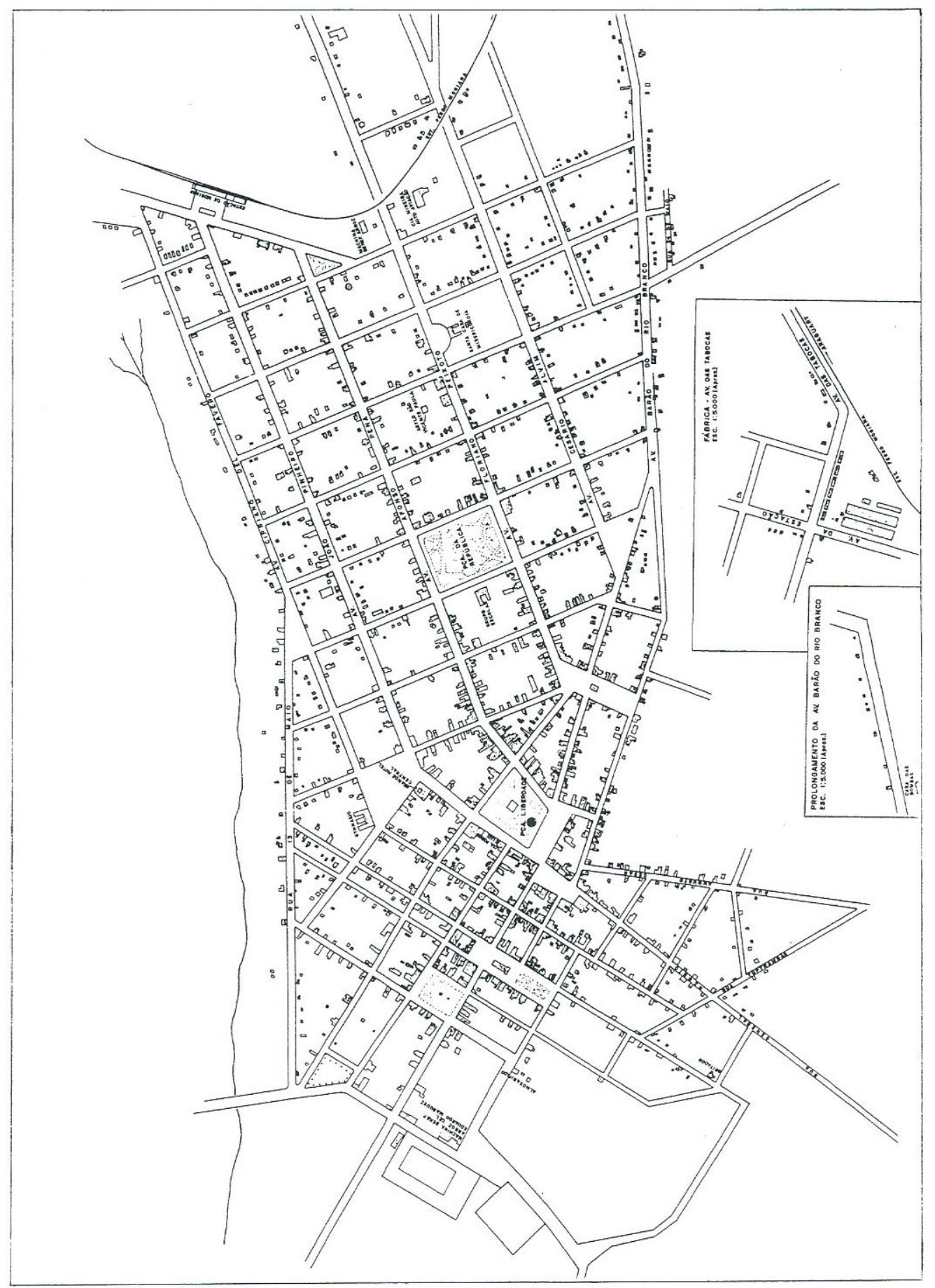

4 Com relação a Uberlândia, este traçado é continuado, mais tarde, apenas na direção das avenidas já referidas. $O$ restante da cidade cresce de forma fragmentada, seguindo parâmetros topográficos e econômicos, em que os loteamentos são abertos por empresas imobiliárias especulativas, muito individualizadas. 


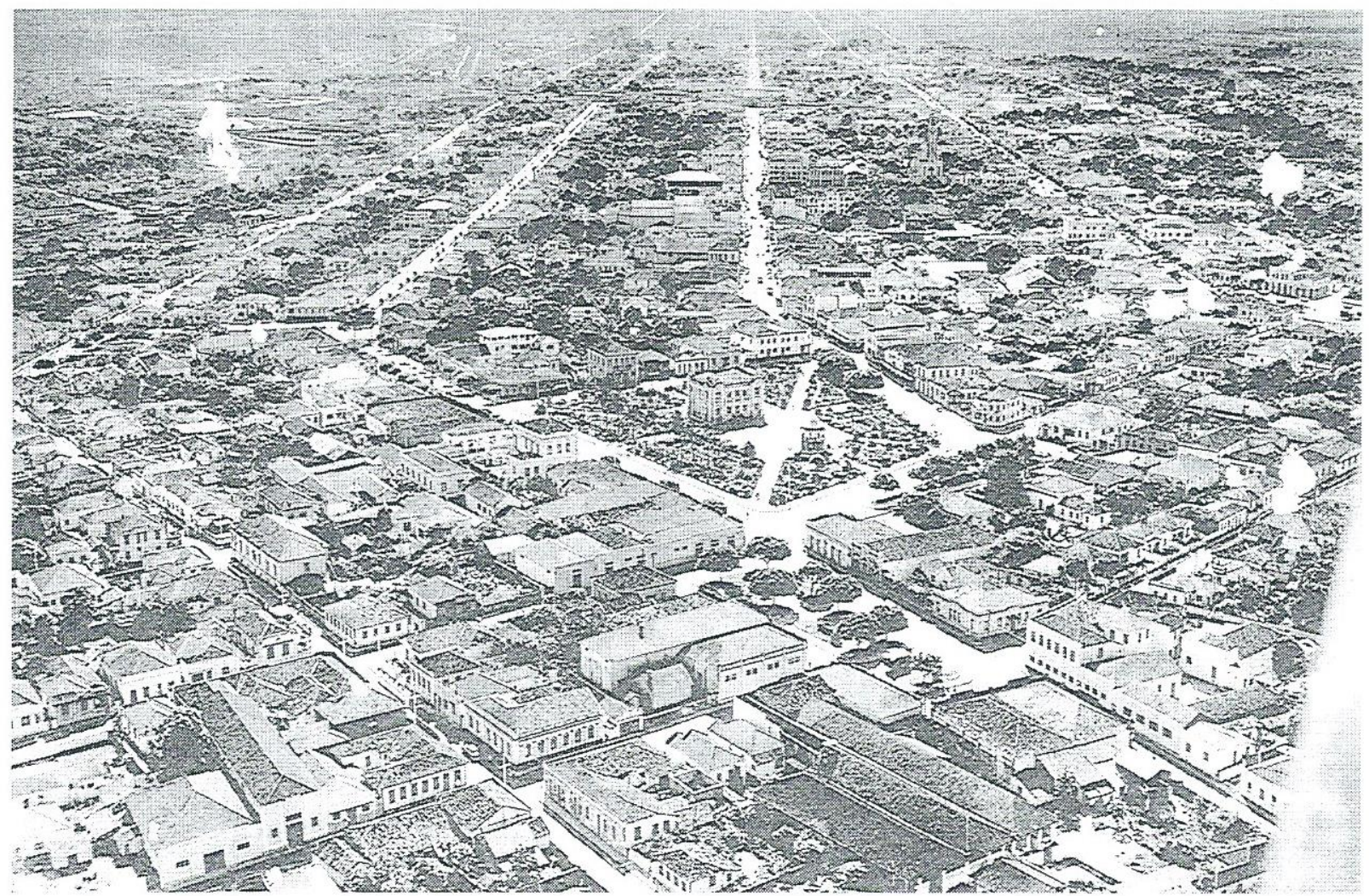

Foto 1: Uberlândia: vista área - anos 40.

Fonte: Arquivo Público Municipal, PMU.

Essas avenidas foram projetadas segundo parâmetros urbanísticos modernos, nos quais as artérias deveriam ser retilíneas e extensas, o que foi muito facilitado pela topografia plana do sítio urbano.

Nada de ruas tortuosas, mas artérias em alinhamento reto, avenidas amplas, na sua maioria na parte central da cidade ou terminando em praças em parte já ajardinadas. As avenidas João Pinheiro, Afonso Pena, Floriano Peixoto, são artérias em que circulam cotidianamente a população no azáfama de incessante

\section{trabalho. (O REPÓRTER, 16/07/ 42:01).}

O referido plano tinha também como objetivo criar uma cidade cuja imagem expressasse a modernidade e a ordem, em um espaço urbano homogêneo e asséptico, que não se assemelhasse ao velho Fundinho, antigo, de ruas estreitas e tortuosas.

A cidade está edificada em local de duas configurações distintas: a cidade velha que atendendo aos imperativos da época, buscou as glebas que se estendem ao longo dos 
ribeirões São Pedro e Cajubá, apresentando suave declive. E a cidade nova já refletindo a mentalidade arrojada da nova geração, se lança rumo à vastidão da chapada, com um traçado geométrico e harmonioso. (CORREIO DE UBERLÂNDIA, 07/04/48:02)

A partir da instalação dessa nova estrutura urbana, os empresários locais passam a investir em imóveis comerciais nas avenidas Afonso Pena e Floriano Peixoto; e na construção de belas e luxuosas residências, nas avenidas Cipriano Del Fávero e João Pinheiro.

Essas avenidas rapidamente receberam serviços públicos básicos, tais como: redes de distribuição de água e de coleta de esgoto sanitário, arborização, iluminação pública e calçamento, para que pudessem ser ocupadas, principalmente, por prédios comerciais e de serviços e residências de luxo.

A paisagem urbana de Uberlândia modificou-se bastante, à medida que a cidade crescia, seguindo o novo caminho criado pelas avenidas, onde se instalaria posteriormente o novo núcleo central.

As antigas residências ali existentes foram, pouco a pouco, desocupadas e demolidas, fazendo surgir, ao longo dos anos $40 / 50$, casas comerciais, serviços e edifícios, que redesenharam o espaço da cidade, mas que, no entanto, expulsaram a população de renda mais baixa, alojada em partes daquela área já há algum tempo.

De outro lado, a elite local, com a constante preocupação em acompanhar o desenvolvimento do país, a partir do início do século $X X$, tentou copiar e/ou imitar, principalmente, projetos arquitetônicos que pudessem levar a cidade a se aproximar da modernidade.

Esse fato pode ser constatado nas construções públicas e privadas, edificadas até a metade do século atual, como por exemplo o Ginásio Mineiro, o Fórum, a Matriz de Santa Terezinha, o Mercado Municipal, a Estação Rodoviária e o Paço Municipal ${ }^{5}$ (FOTO 02 e 03).

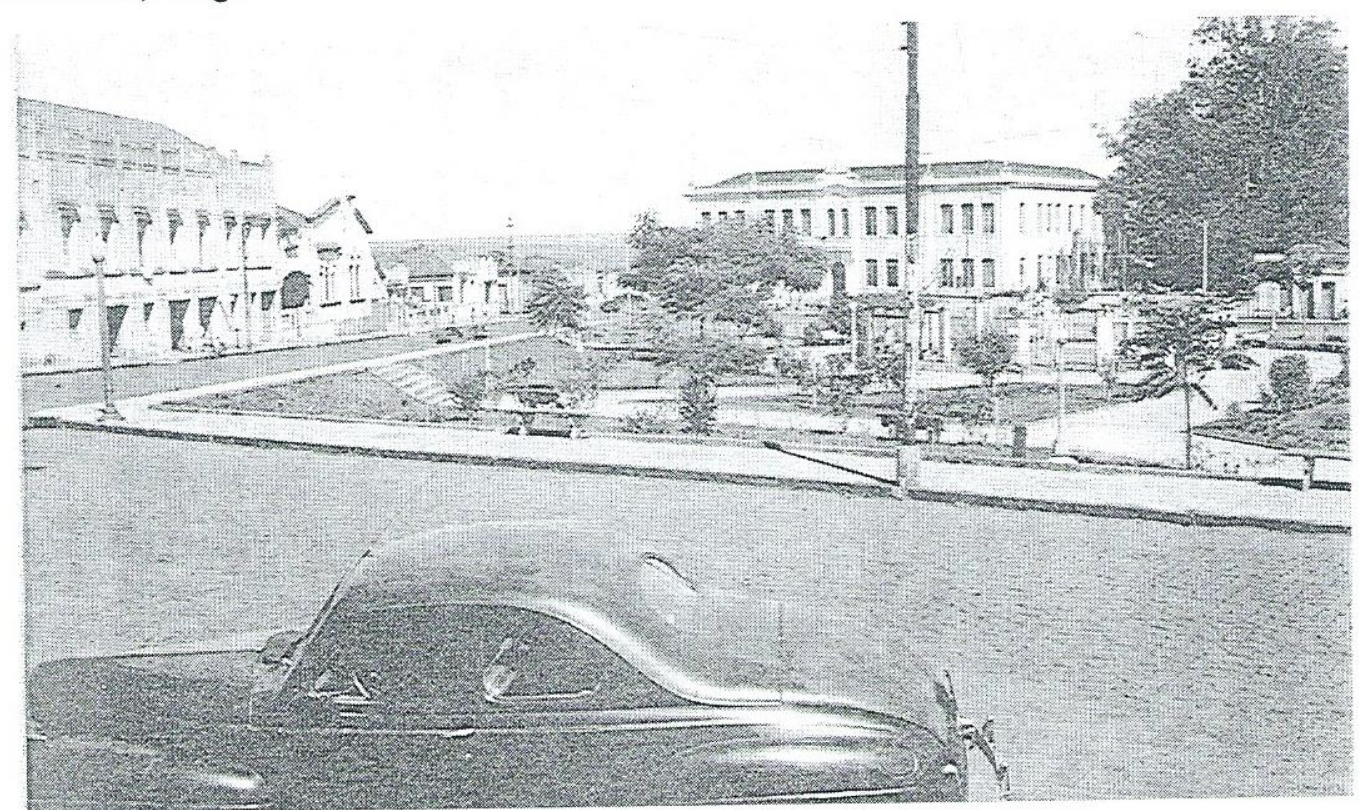

Foto 2: Uberlândia: Ginásio Municipal - 1940. - Fonte: Arquivo: Álvaro Abbott Soares.

\footnotetext{
Matriz de Santa Terezinha - 1941, Ginásio Mineiro - 1913, Estação Rodoviária - 1946, Mercado Municipal - 1944 e Paço Municipal - 1917, algumas em estilo neoclássico e outras modernistas.
} 


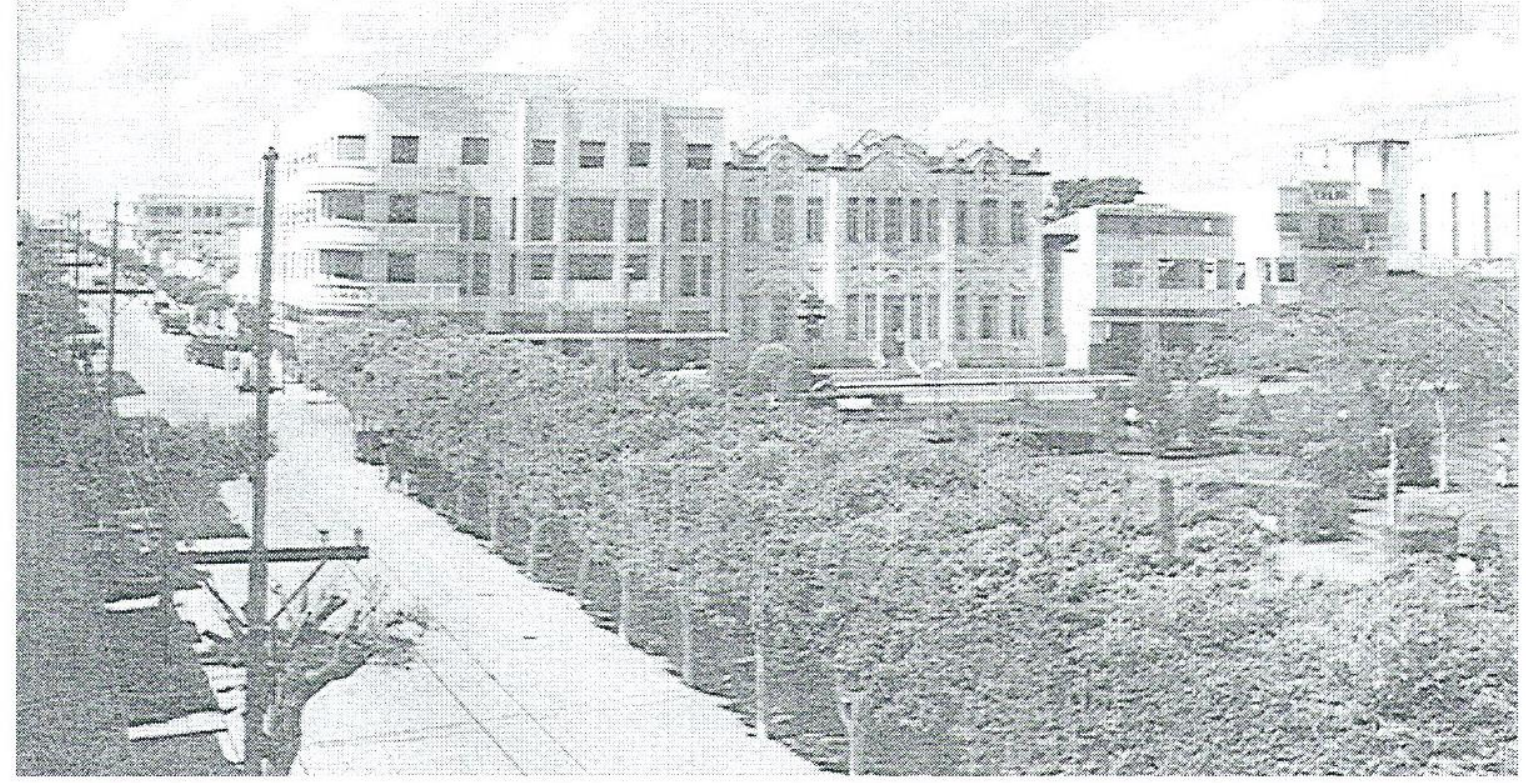

Foto 3: Uberlândia: Fórum e Hotel Colombo - 1940.

Fonte: Arquivo: Álvaro Abbott Soares.

Dentre as obras que contribuíram para materializar o discurso do progresso na cidade, podemos destacar o prédio da antiga

Prefeitura Municipal, localizado na atual praça Clarimundo Carneiro (FOTO 04).

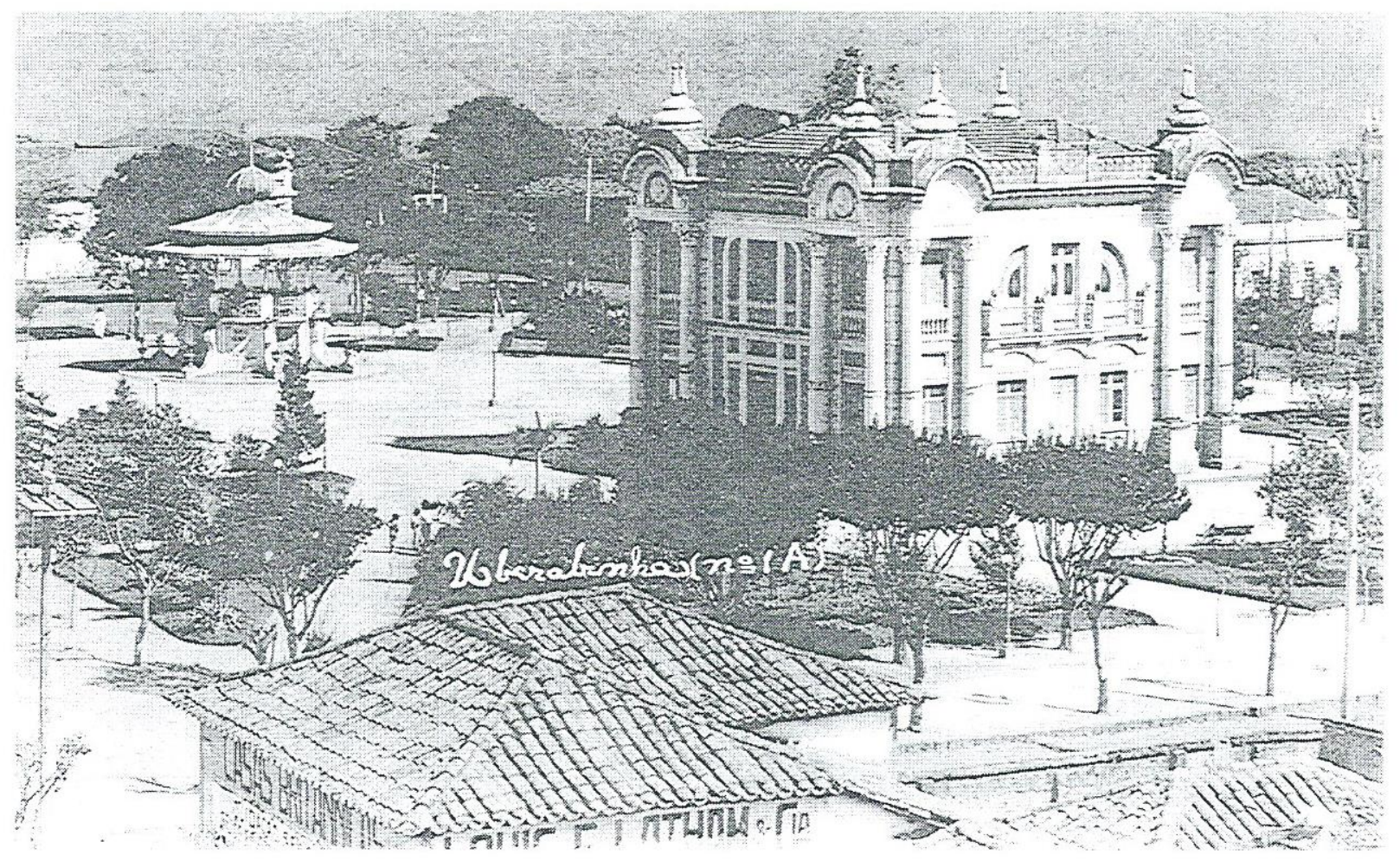

Foto 4: Uberlândia: Paço Municipal - 1920.

Fonte: Arquivo Público Municipal, PMU. 
O antigo Paço Municipal, com projeto do engenheiro-arquiteto Cipriano Del Fávero, foi inaugurado em 1917, e é atualmente um dos poucos prédios tombados pelo Patrimônio Municipal. Quando foi construído, encantou a população por sua beleza e imponência arquitetônica.

Num primeiro momento, sua construção, que obedecia aos critérios e características dos prédios institucionais do começo do século $X X$, criou até um certo assombro e admiração entre os moradores da cidade, uma vez que era a primeira obra arquitetônica que possuía dois pavimentos.

O importante prédio do Paço Municipal é obra também do passado, obra que pela sua elegância e arrojada concepção, desafia o presente e chega a se impor galhardamente construindo traço marcante no arrojo de nosso antecessores, no afã de algo a realizar como visos de imortalidade. Quem poderá negar que há poesia e arte naquele belo edifício que é ainda sede da Prefeitura. (REVISTA ELITE, março/58:07).

Esse edifício exprimiu a face da cidade progressista, ordeira e majestosa que tentava ser Uberlândia e, com o passar dos anos, constituiu-se em um símbolo, um referencial urbano para os seus moradores. Esse talvez tenha sido o primeiro projeto arquitetônico que expressou a dinâmica política e econômica das elites locais, postura esta que vem se perpetuando, até os dias atuais.

Desde os primórdios do século $X X$, o espaço da cidade foi sendo ordenado, segundo parâmetros de ordem, progresso e monumentalidade, pelos quais os valores políticos e sociais da elite dominante eram reportados à sua imagem urbana, uma vez que exprimiam a sua superioridade, seu senso de ordem e eficiência. Enfim, reproduziam a cidade e as suas obras à sua imagem e semelhança.
Desde os anos 30/40 deste século, Uberlândia foi popularmente denominada de Cidade Jardim, em função do intenso controle de sua feição urbana, fosse pela limpeza de suas avenidas e ruas; do extremo cuidado com as moradias e prédios comerciais, ou pela existência de inúmeras praças e jardins (FOTO 05).

Era uma cidade famosa pela beleza de suas praças arborizadas e ajardinadas, cujos canteiros floridos encantavam, sobretudo, pela flores perfumosas. Os jardins que eram verdadeiros recantos e que convidavam a um descanso, numa tarde quente ou numa noite enluarada. Tudo nela era admirado. Ruas limpas, passeios em estado perfeito, avenidas bem cuidadas. Dava gosto passear mesmo sem destino, só pelo prazer de contemplar-Ihe a beleza e o que mais saltava aos olhos, a limpeza. (CORREIO DE UBERLÂNDIA, 19/03/ 53:03). 


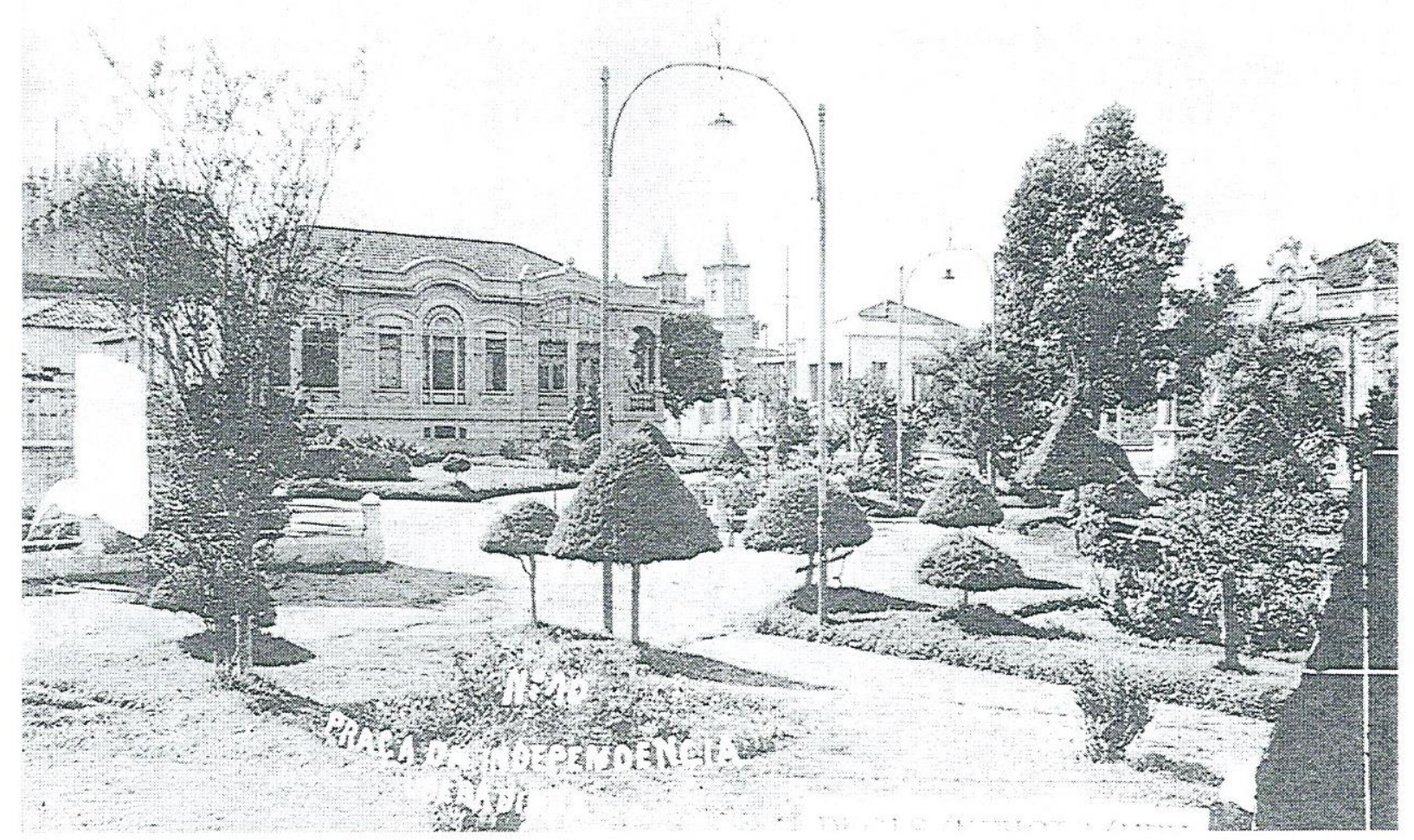

Foto 5: Uberlândia: Praça da Independência - 1940.

Fonte: Arquivo Público Municipal, PMU.

Tanto era verdadeira a preocupação com a ordem e higienização da cidade que a imprensa escrita, cotidianamente, chamava a atenção para a conservação e estética dos edifícios, inclusive mostrando a necessidade de demolir, no centro da cidade, aqueles mal conservados; manutenção da limpeza dos logradouros públicos, uma vez que sujeira e desordem nas ruas e praças eram sinônimos de atraso, doenças.

Há prédios nas praças e avenidas mais beneficiadas, que carecem de limpeza externa; há prédios que já deveriam ter sofrido demolição para dar lugar a outros de melhor arquitetura.. É razoável que se faça aqui apelo para que em certas zonas urbanas desapareçam umas casas antigas que fazem jús à designação de pardieiros e que outras sejam convenientemente reformadas $e$ ainda a umas terceiras seja explicada periodicamente a limpeza externa que a aristocracia urbana decreta no seu regulamento. (O REPÓRTER, 17/02) 45:01).

Para que possamos entender o significado da denominação Cidade Jardim, em Uberlândia, é preciso lembrar que não há nenhuma relação entre a mesma e as concepções das garden cities inglesas de HOWARD (1889).

Essas eram cidades planejadas para aproximadamente 32 mil habitantes, cuja concepção previa uma combinação entre as 
melhores qualidades da cidade com seus serviços públicos e atividades sociais, com as vantagens do campo, de áreas verdes, tranqüilidade e salubridade. As aglomerações, assim projetadas, solucionariam a questão do isolamento da vida rural e o congestionamento populacional/residencial das cidades (RELPH, 1990).

Em Uberlândia, a história foi bem outra. Segundo o jornalista Lycidio Paes (CORREIO DE UBERLÂNDIA, 20/03/70:06) este cognome partiu de um representante da revista Noite llustrada - que foi chamado para fazer um relatório sobre a cidade, com vistas à propaganda do município naquele periódico, ainda nos tempos da ditadura Vargas.

O que sei é que "Cidade Jardim" é invenção de um repórter de pouco sizo de "Noite llustrada" (quando essa revista pertencia ao Governo ditatorial) que aqui esteve para fazer propaganda do município e levou na bagagem aquela originalidade intempestiva bem paga pelos cofres da Prefeitura.

De acordo com esse jornalista, o repórter apenas recolheu algumas fotografias e andou pelo centro da cidade, inclusive, num período em que a mesma passava por um verão quente e seco muito rigoroso, que fez com que as áreas verdes ficassem completamente ressequidas. E, de posse destas informações, escreveu sobre a bela paisagem urbana, principalmente, sobre suas praças públicas, e apelidou Uberlândia de Cidade Jardim.

Alguém deu a Uberlândia o nome de "cidade jardim". E a história pegou, porque o nome foi bem lembrado, Uberlândia é uma cidade enfeitada de belos e aprazíveis jardins. Um magnífico conjunto que, somente na parte urbana, sobe a um número superior a dez. Onde quer que se vá, estão os jardins floridos, arranjados com capricho. (CORREIO DE UBERLÂNDIA, 24/02/50:01).

Esta denominação perdurou por várias décadas, como o principal referencial de identificação de Uberlândia, e, por isso mesmo, a população e a administração municipal sempre a conservaram ordenada e limpa, como podemos observar na citação abaixo:

Ao saltar da Mogiana e caminhando pelas ruas e avenidas centrais da urb de imediato percebi o bom gosto de seu traçado nas suas amplas avenidas, nos seus belos jardins públicos; na arborização e pavimentação de suas principais vias; nos seus edifícios que revelam o apurado gosto estético da moderna e higiênica arquitetura, fábricas, igrejas, instituições hospitalares, como nos prédios públicos, etc., e até mesmo boa parte de suas residências particulares primam de arte construtiva e ornamentação da jardinagem. (CORREIO DE UBERLÂNDIA, 17/02/45:01).

Essa constante preocupação com a ordem e estética das avenidas, ruas e praças e moradias, também ocorria em relação à instalação de serviços públicos, bem como os projetos arquitetônicos, que, mesmo com construções modestas, tinham linhas arrojadas e modernas.

Para que essa paisagem urbana fosse mantida, políticas de higienização foram impostas aos moradores, não sendo permitido jogar lixo nas ruas, pois o serviço de limpeza era muito rigoroso; as fachadas dos prédios deveriam ser pintadas anualmente; os passeios públicos eram constantemente consertados; e as praças reformadas. Existia, ainda, um manual com normas de manutenção de limpeza da cidade, e inclusive, até os pedintes eram 
retirados das áreas públicas, como forma de limpar as ruas.

Semanalmente, era feita uma verificação por equipes de fiscalização da prefeitura, tendo em vista assegurar a ordem, a limpeza e a aparência da cidade, uma vez que estas exprimiam a saúde e o bem-estar da população, enfim, a prosperidade da cidade.

Também com o objetivo de assegurar - lugar de Uberlândia como centro regional, o principal lema difundido pela Administração Municipal a partir dos anos 40 era:

Cidade Jardim - ordem, progresso e beleza. Uberlândia, na ânsia de crescer, na pressa de progredir e aumentar, no desejo de expandir, não se esqueceu que o "it" principal de uma grande cidade é a limpeza, a ordem e as belezas. (O REPÓRTER, 19/10/52:02).

Nesse sentido, uma das principais preocupações dos administradores eram os jardins, as praças públicas, que somavam 13, no final da década de 40 , tratados com excessivo esmero e cuidado, mesmo nos longos e cíclicos períodos de seca, característicos dessa região, como pode ser observado pela Foto 04, que retrata a antiga Praça da República (atual Praça Tubal Vilela).

Isso faz com que os nossos belos jardins permaneçam sempre floridos, embelezando assim cada vez mais essa encantadora "Cidade Maravilhosa" nascida no mato, no sertão de Minas e transformada pela mão do homem numa cidade, numa grande e próspera cidade, numa "Cidade Jardim". (O REPÓRTER, 19/ 10/51:02).

As praças públicas eram o orgulho e alegria das pequenas cidades do interior do país, pois eram ali realizadas as festas religiosas, cerimônias oficiais, as manifestações populares, enfim todo o movimento cotidiano da cidade, no que diz respeito às festas e comemorações públicas.

SITTE (1992:17) analisando o significado das praças públicas, diz que nas cidades antigas, as praças principais eram uma necessidade vital de primeira grandeza, ma medida em que ali tinha lugar uma grande parte da vida pública, que hoje ocupa espaços fechados, em vez de praças abertas.

As praças e os jardins tinham, até esse período, um importante significado público, pois eram os locais onde as pessoas se encontravam para conversar, namorar, distrair, jogar, ouvir a banda de música. Em seu espaço interno ou no seu entorno, localizavam-se as construções monumentais da cidade e os seus principais pontos de referência: a Matriz de Santa Terezinha, lojas comerciais, o Paço Municipal, os bancos, as residências da elite, cinemas, restaurantes, entre outros.

\begin{abstract}
A praça Tubal Vilela é a sala de visitas de Uberlândia, galhardamente onde a família uberlandense se encontra $e$ se diverte com todos os seus atrativos de mil e uma noites na sua deslumbrante fonte onde se escuta a ópera, o lago dos cisnes, a concha acústica e mais humano ainda os amigos se encontram. (CORREIO DE UBERLÂNDIA, 20/05/59:02).
\end{abstract}

Tratamento semelhante era dado também ao calçamento das principais avenidas, ao abastecimento de água, à iluminação pública nas áreas centrais, às novas construções públicas e privadas, serviços merecedores de parcelas expressivas dos investimentos municipais, tendo em vista a importante contribuição que eles costumam prestar na criação e manutenção da imagem pretendida para a cidade. 
A CIDADE JARDIM: DO CENTRO AOS BAIRROS- AS DIFERENTES FORMAS DE USO E OCUPAÇÃO DO SOLO URBANO E A CONSTRUÇẨO DA IMAGEM URBANA

As diferentes formas de uso do solo urbano são resultado do processo de divisão do trabalho, em que determinados agentes se apropriam de forma diferenciada da cidade. Assim, quanto mais intenso for esse processo, tanto maior será a sua subdivisão em espaços singulares, particulares, que podem servir como suporte às atividades urbanas.

A cidade constitui, em si mesma, o lugar de um processo de valorização seletivo. Sua materialidade é formada pela justaposição de áreas diferentemente equipadas, desde as realizações mais recentes, aptas aos usos mais eficazes de atividades modernas, até o que resta do passado mais remoto. [...] Cada lugar, dentro da cidade, tem uma vocação diferente, do ponto de vista capitalista, $e$ a divisão interna do trabalho a cada aglomeração não the é indiferente. (SANTOS, M. 1994:130).

Para LEFEBVRE (1983:46), o centro urbano implica e propõe a concentração de tudo o que se dá no mundo, na natureza $e$ no cosmos: produtos da terra, produtos industriais, obras humanas, atos e situações, signos e símbolos.

Neste sentido, o centro comercial, considerado o motor da vida cotidiana, apresenta-se como a principal área da cidade no que diz respeito à concentração de atividades comerciais e de serviços, fluxos financeiros e de informação, transportes, onde os diversos atores da cidade encontram-se para consumir suas necessidades.

Estão aí também concentrados ás áreas apropriadas ao lazer e recreação noturna, moradias, monumentos e prédios históricos. Enfim, é o lugar do movimento, animação e consumo e, sendo assim, o núcleo central de uma cidade é um produto histórico, uma vez que expressa as transformações das fases de estruturação político, econômica e social do território.

BEAUJEU GARNIER (1983:339), assim define os núcleos centrais das cidades:

o centro de negócios é a própria expressão do poder urbano, o coração vivo da cidade. Pela sua localização e extensão, pelos tipos de atividades nele concentrados, 0 estado de modernismo ou de abandono que revela, os trabalhos que the asseguram a permanência, o progresso ou a reconquista, o centro de negócios traduz as fases da vida urbana, a sua continuidade ou alternância, os efeitos da política administrativa, assim como os das capacidades financeiras locais, nacionais e, por vezes, internacionais.

CORRÊA (1989:38), em seus estudos sobre a organização interna das cidade, conceitua o núcleo central de uma cidade da seguinte forma:

A área central constitui-se no foco principal não apenas da cidade mas também de sua hinterlândia, nela concentram-se a principais atividades comerciais, de serviços, da gestão pública e privada; e os terminais de transporte inter-regionais e intraurbanos. Ela se destaca na paisagem da cidade, pela sua verticalização.

Nesse mesmo caminho, SPOSITO (1991:06), expõe sua concepção sobre o tema, inclusive apontando sua direção na cidade: 
No interior da cidade, o centro não está necessariamente no centro geográfico, e nem sempre ocupa o sítio histórico onde esta cidade se originou, ele é antes de tudo ponto de convergência/divergência, é o nó do sistema de circulação, é o lugar para onde todos se dirigem para algumas atividades e, em contrapartida, é o ponto de onde todos se deslocam para a interação destas atividades aí localizadas com as outras que se realizam no interior da cidade ou fora dela.

Mas qual era o significado do núcleo central de Uberlândia nos anos 40 e 50? Constituía-se no lugar para onde se convergiam as pessoas a fim de trabalhar e divertir-se, descansar, encontrar amigos, pois ali se concentravam os setores de consumo e de serviços públicos e privados; as áreas destinadas ao lazer e religiosidade; os entroncamentos das principais vias públicas. Sinteticamente, os mais importantes pontos de referência da cidade.

Estavam aí localizados também os principais edifícios públicos e privados, que se tornaram, ao longo do tempo, símbolos de Uberlândia e referência para os seus moradores. Dentre eles podemos destacar, o Hotel Colombo, o Fórum, o Grupo Escolar Bueno Brandão, importantes referenciais urbanos até os anos 1970.

Infelizmente, esses expressivos testemunhos da história da cidade não perduraram até os dias atuais. Sem qualquer preocupação por parte dos administradores e nenhum clamor público, foram demolidos, para em seus lugares serem construídos arranha céus, lojas de departamentos e novas escolas.

Já dissemos que Uberlândia tem um verdadeiro pavor de seu passado. Ela vive procurando destruir as marcas das gerações passadas, numa corrida desenfreada para o que é moderno e funcional. Desapareceu agora o sobradão onde funcionava o Fórum e assim será com outros tantos pontos de referência da cidade. (CORREIO DE UBERLÂNDIA, 1981:07).

O núcleo central de Uberlândia, historicamente, foi o espaço polarizador da cidade, somente a partir de meados da década de 80 , as atividades econômicas passaram a deslocar-se para novas áreas urbanas, sendo algumas delas criadas para esse fim, como por exemplo os shoppingcenters.

Ao longo do tempo, o centro da cidade foi centralizando diversas atividades comerciais a varejo, serviços especializados, áreas destinas a lazer e cultura. Tornou-se assim, um importante centro para a circulação do capital, à medida que se constitui em um centro de consumo para as cidades do Triângulo Mineiro, Alto Paranaíba e Sul de Goiás. (SOARES \& RAMIRES, 1994:30).

No universo entre as praças da Estação da Mogiana (atual Sérgio Pacheco) e Antônio Carlos (atual Clarimundo Carneiro), e as avenidas Afonso Pena e Floriano Peixoto, consolidou-se, nos anos 40 , o principal setor de comércio varejista, de serviços e lazer da cidade, como mostram a FOTO 06 e a FIGURA 03.

Era ali que as pessoas iam trabalhar, encontrar-se nos cafés, confeitarias, bares, cinemas e no clube social; participar dos footings ao longo da avenida Afonso Pena, entre as praças Antônio Carlos (atual Clarimundo Carneiro) e República (atual Tubal Vilela), como pode ser observado pela FOTO 07. 


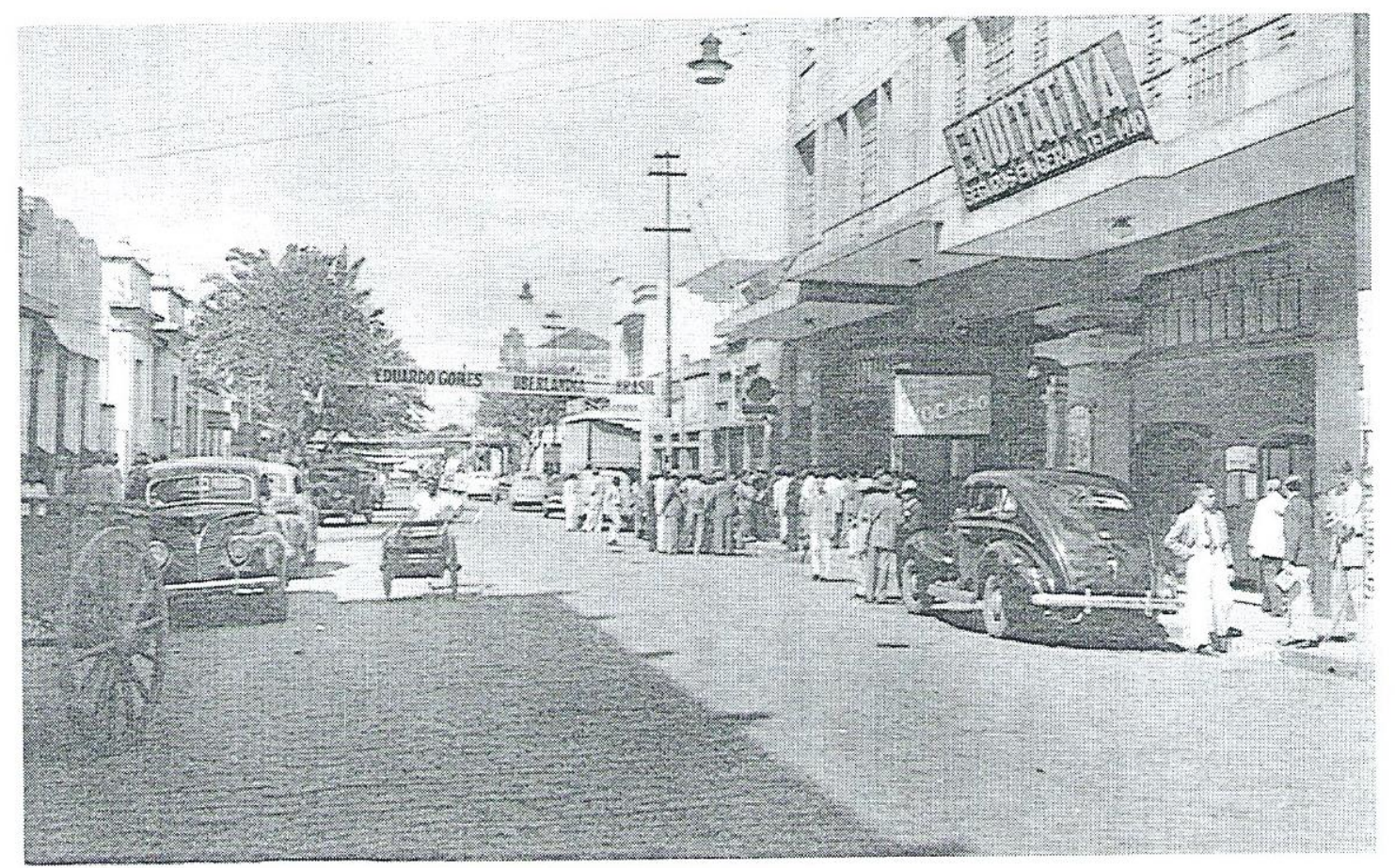

Foto 6: Uberlândia: Avenida Afonso Pena - 1940.

Fonte: Arquivo: Álvaro Abbott Soares.

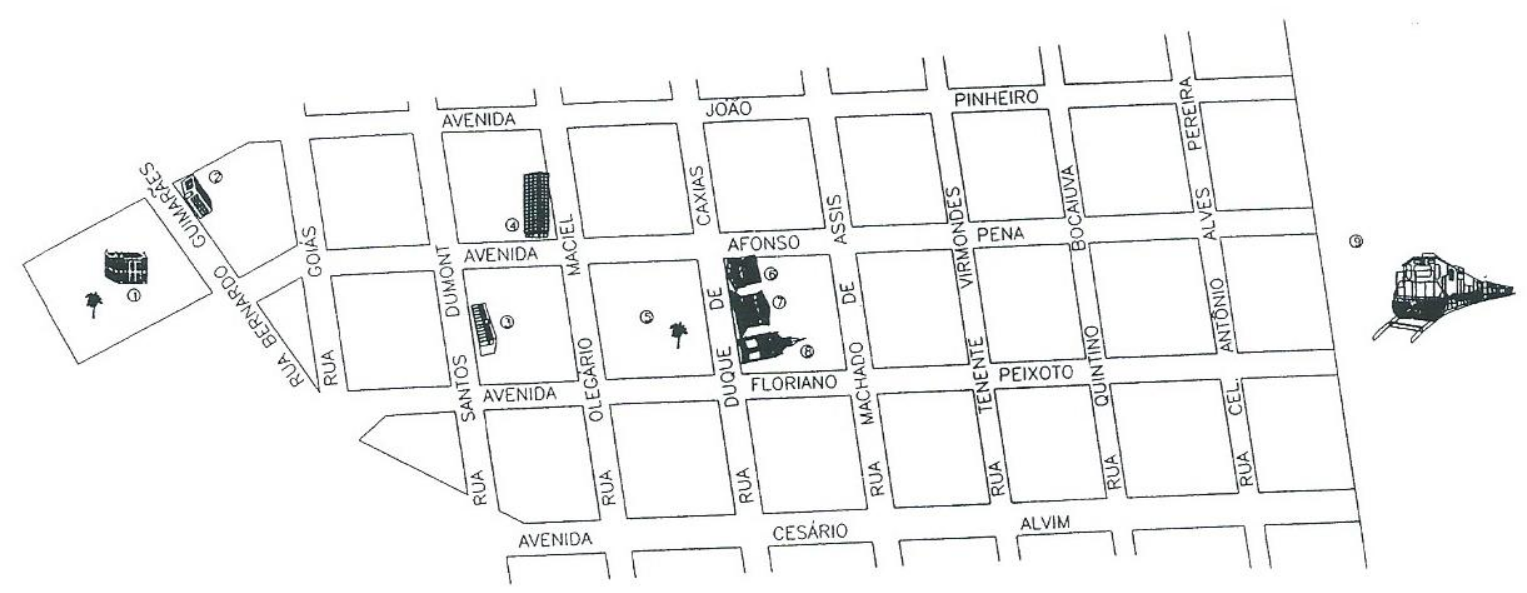

LEGENDA
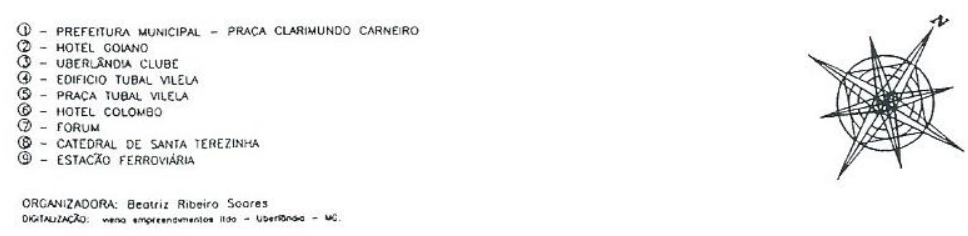

Figura 3: Uberlândia: Núcleo Central com principais sígnos e símbolos urbanos - anos 40/50. Fonte: Arquivo: Álvaro Abbott Soares. 
Incontestavelmente, a avenida Afonso Pena é o coração da cidade e centro de seu intenso e ativo comércio. Aí é que estão localizados os dois cinemas e os estabelecimentos bancários, as mais esplendorosas vitrines de conceituadas lojas [...] os mais importantes atacadistas e grande número de postos de serviço para automóveis. (CORREIO DE UBERLÂNDIA, 1947:01).

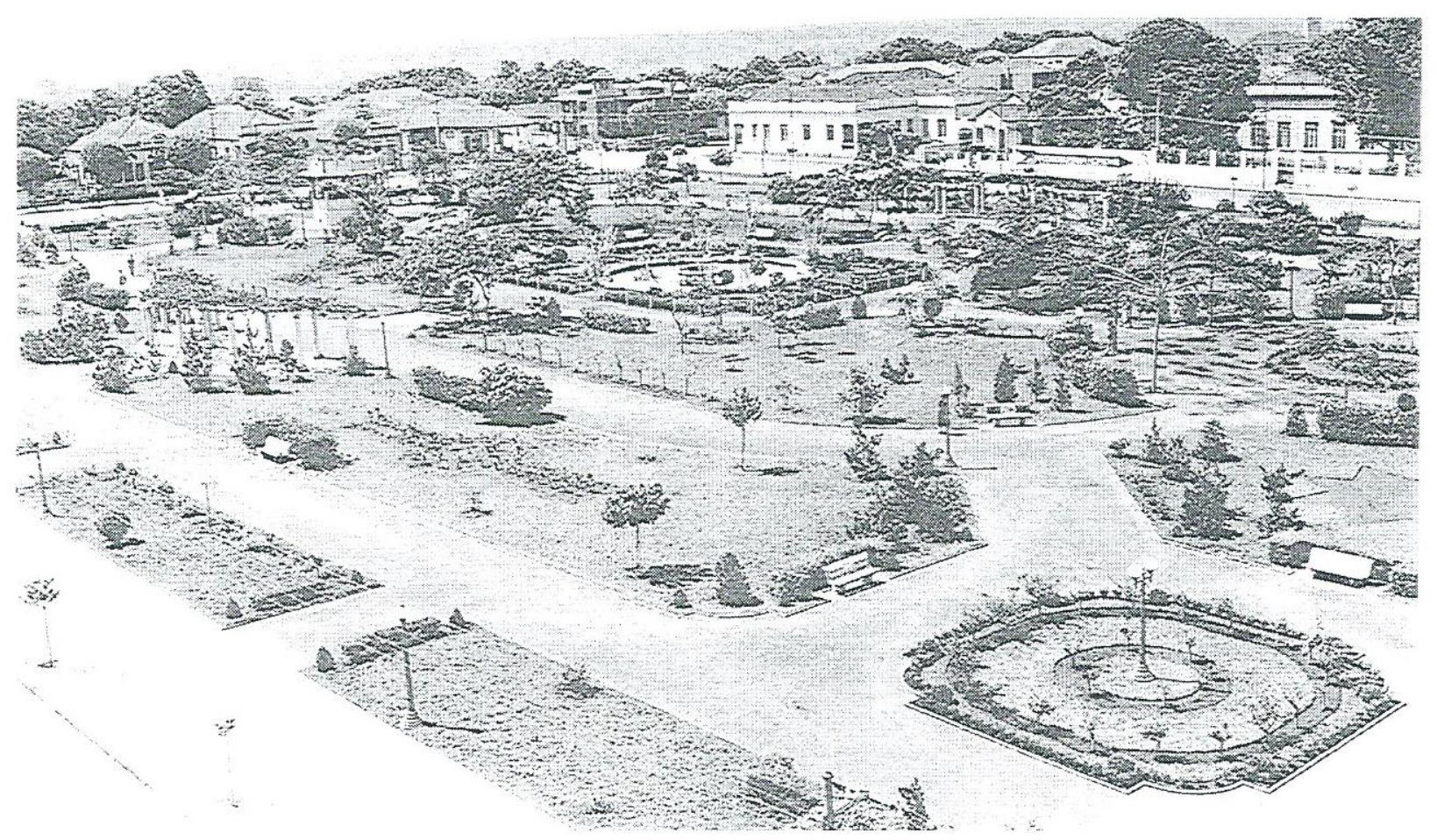

Foto 7: Uberlândia: Praça da República - 1940.

Fonte: Arquivo Público Municipal, PMU.

No entorno do centro, principalmente entre as avenidas João Pinheiro e Cipriano Del Fávero instalou-se, a partir de meados da década de 30 , a elite política e econômica em suas mansões e palacetes luxuosos. Os mesmos foram construídos por arquitetos famosos, com projetos sofisticados, tornando a fisionomia da cidade cada vez mais elegante e moderna (FOTO 08). 


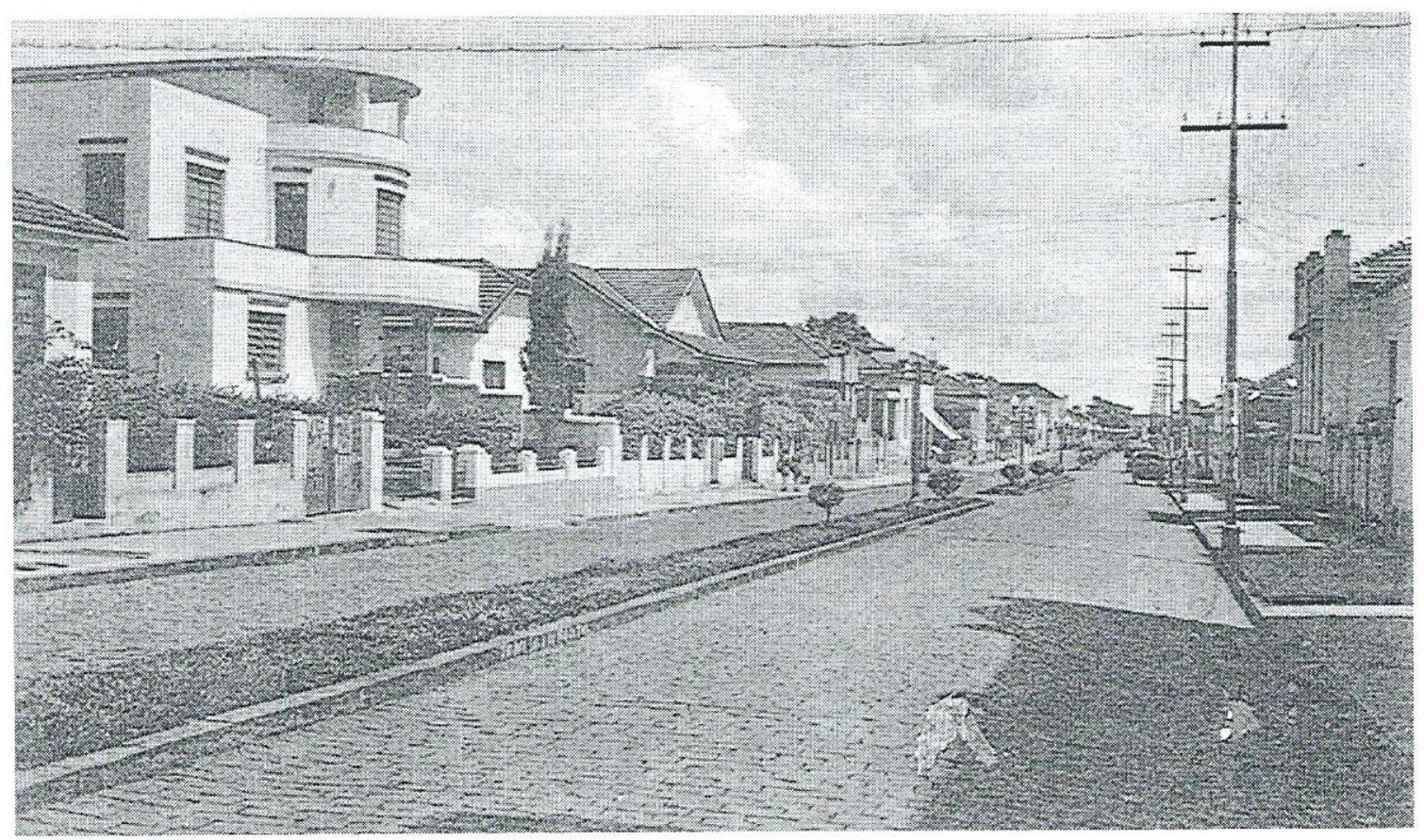

Foto 8: Uberlândia: Avenida João Pinheiro - 1940.

Fonte: Arquivo: Álvaro Abbott Soares.

A avenida João Pinheiro passou em 1939 por uma reformulação urbanística, recebendo novo calçamento, ajardinamento central, iluminação por meio de linha subterrânea, com postes duplos centrais, para melhor abrigar essas construções.

É assim que todos os dias surgem novos palacetes e reformam-se as fachadas dos antigos, tornando a fisionomia da cidade cada vez mais elegante e moderna. Ainda agora estão sendo concluídos dois prédios que mereciam menção especial pelo que trazem de embelezamento para a avenida João Pinheiro, a que reúne os melhores projetos arquitetônicos, no que se refere ao setor residencial. São, na verdade, construções de bom gosto, de preço elevado, seduzindo cada uma pelas particularidades de concepção da sua planta. (CORREIO DE UBERLÂNDIA, 01/02/45:02).

Esse espaço urbano ficou reservado apenas para as residências de alto luxo, não podendo ali serem construídas casas comerciais, moradias populares, o que fez com que se fragmentasse ainda mais a cidade.

Sob a influência dessa preocupação não será oportuno que a Prefeitura volva as suas vistas para a avenida João Pinheiro, onde já se acham os primeiros prédios residenciais da cidade, e onde provavelmente serão construídos muitos de igual teor, para que não se escasseiem datas vagas ou ocupadas por verdadeiros pardieiros. [...] Julgamos que nessa via, que é a mais bella de Uberlândia, a prefeitura deveria evitar a construção de armazéns e prédios de aparência secundária, bem como submeter todos os projetos a um estudo meticuloso no que se refere as suas linhas em confronto e em harmonia com o conjunto existente. (O REPÓRTER, 25/01/41:01).

Atualmente, as casas vêm abrigando lojas e serviços especializados, mas de qualquer forma preservam a memória da cidade, uma vez que esse patrimônio 
edificado tem uma importância local como preservação da memória de Uberlândia.

Na década de 50 , com a construção de Brasília e a abertura de estradas interligando a nova Capital Federal e São Paulo, Uberlândia conhece um rápido crescimento, e visíveis transformações ocorrem em sua área central, como podemos observar na citação abaixo:

As formas anatômicas de aço e granito colorem as ruas de Uberlândia, onde centenas de portas de comércio tragam e expelem milhares de pessoas na sinfonia alegre do desenvolvimento. Esqueletos enormes preenchem os vazios, vaticinando crescimento de uma cidade que não pára. Tem de tudo o comércio de Uberlândia. Os luminosos à noite no pisca-pisca "metropolitano" lembram as grandes cidades adormecidas. (CORREIO DE UBERLÂNDIA, 15/08/57:02).

Começa, a partir daí, uma nova fase de crescimento da cidade, impulsionada pelas transformações que ocorriam no país. Seu núcleo central expande-se, englobando áreas circunvizinhas, e outros embriões de núcleos comerciais, com lojas de atendimento emergencial, são iniciados nos bairros mais populosos da cidade, gerando melhoramentos na infra-estrutura dessas áreas e em sua estética.

Entretanto, essas transformações não atingiram a população residente nos bairros mais afastados da área central, denominados, até aquele momento de vilas ou subúrbios, tais como: Martins, Operário, Roosevelt, Osvaldo, Tubalina e Saraiva.

Não têm água, com que sirvam nas suas labutas. A iluminação das ruas também lhes falta, sem explicações convincentes. Impõe-se por conseqüência, ação mais eficiente por parte do Governo Municipal no sentido de propiciar melhor nível de vida àqueles que continuam asfixiados por angustiantes problemas. (O REPÓRTER 19/04/55:02).

Nesses bairros, persistia o problema da falta de água para abastecer a população; as ruas transformavam-se em verdadeiros lamaçais no tempo das chuvas; a iluminação pública era muito precária; os terrenos vazios viravam depósitos de lixos e entulhos; o traçado urbano não obedecia a critérios técnicos, assim como a arquitetura de suas habitações.

Os problemas de infra-estrutura agravavam-se ao longo do tempo, sobretudo, em virtude do crescimento urbano, gerado pelo aumento da população e de um novo agente de produção do espaço, que passou a fazer parte da dinâmica urbana da cidade, a partir de meados da década de 30 , a empresa imobiliária:

As vilas que circundam esta cidade em semicírculos, com exceção apenas da parte mais antiga, são aglomerados de população que começaram a se formar por volta de 1924. Nesse ano era uma ou outra casa erguida na vila Martins, na vila Osvaldo, na vila Operária. Com o correr do tempo essas edificações foram se multiplicando de forma que em 1940, já as vilas eram numerosas, principalmente depois que a Empresa Imobiliária foi fundada e passou a adquirir terrenos para loteá-los e vendê-los à prestação. Hoje cada vila representa um grande contingente demográfico (CORREIO DE UBERLÂNDIA, 04/02/45:02).

Essa empresa e tantas outras incorporadoras imobiliárias, criadas ao longo da história da cidade, foram as principais responsáveis pela ampliação do perímetro urbano, tendo em vista as facilidades 
observadas decorrentes da inexistência de leis e normas que ordenassem o seu crescimento; a topografia plana favorável; e, principalmente, o arrojo incontido de seus especuladores. A FIGURA 04 abaixo apresenta o crescimento horizontal de

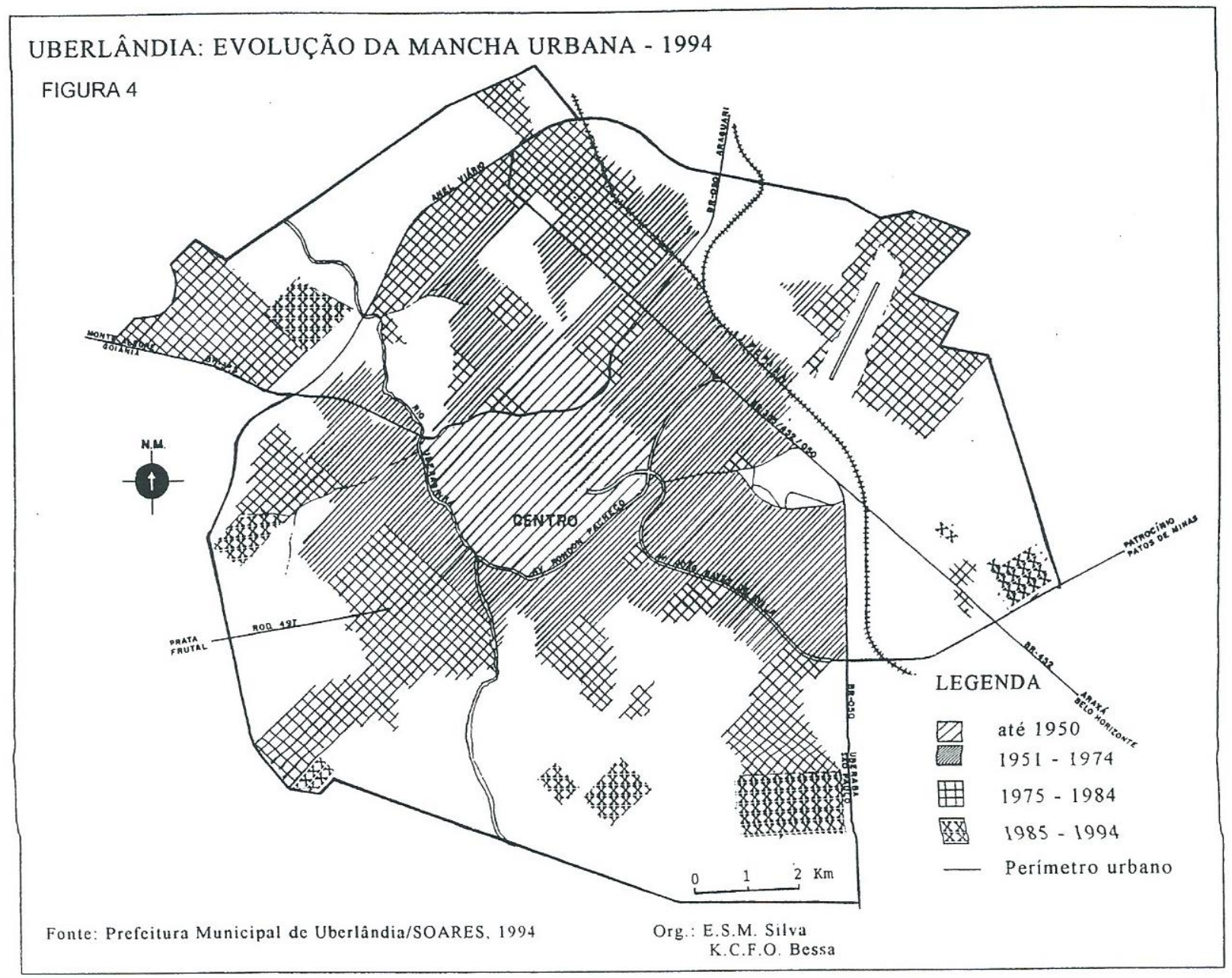

Figura 4: Uberlândia: Evolução da Mancha Urbana - 1994

Fonte: Prefeitura Municipal de Uberlândia/SOARES, 1994

Org.: E.S.M. Silva, K.C.F.O. Bessa 
Uberlândia entre os anos 1900/1990, em que podemos observar os momentos de maior expansão da cidade.

Em 1938, a oferta de terrenos cresceu quase $50 \%$, uma vez que passou de $5 \mathrm{mil}$ para 7,2 mil terrenos, num período em que a população quase não se altera (19.633 hab. - 1937 e 20.114 hab. - 1938). Seis anos mais tarde, entre 1945/46, o número de lotes lançados no mercado cresce de 8 mil para 12.193, quando a população aumenta, apenas 500 habitantes. 0 mesmo acontece em 1953/54 quando esse número passa de 14 mil para 23.600 habitantes.

Podemos constatar também essa prática de expansão horizontal da cidade, pelo levantamento estatístico do Gabinete de Planejamento da Prefeitura - 1985, na TABELA 01, onde são destacados os períodos em que a cidade cresceu desproporcionalmente, levando-se em consideração a população e a relação de lotes existentes.

\section{TABELA 01- UBERLÂNDIA: LOTES EXISTENTES - 1938/1958}

\begin{tabular}{lccc}
\hline ANOS & $\begin{array}{c}\text { POPULAÇÃO } \\
\text { URBANA }\end{array}$ & $\begin{array}{c}\text { LOTES } \\
\text { EXISTENTES }\end{array}$ & $\begin{array}{c}\text { TAXA DE } \\
\text { OCUPAÇÃO }\end{array}$ \\
\hline 1.936 & 19.152 & 5.000 & 0,957 \\
1.937 & 19.633 & 5.000 & 0,982 \\
1.938 & 20.114 & 7.100 & 0,708 \\
1.939 & 20.596 & 7.100 & 0,725 \\
1.940 & 21.077 & 7.100 & 0,742 \\
1.943 & 25.694 & 7.100 & 0,905 \\
1.944 & 27.233 & 7.998 & 0,851 \\
1.945 & 28.772 & 12.193 & 0,589 \\
1.946 & 30.311 & 13.443 & 0,564 \\
1.947 & 31.850 & 13.590 & 0,586 \\
1.951 & 40.000 & 13.590 & 0,736 \\
1.952 & 43.500 & 14.167 & 0,768 \\
1.953 & 47.042 & 23.626 & 0,498 \\
1.954 & 50.567 & 26.075 & 0,485 \\
1.955 & 54.092 & 27.246 & 0,496 \\
1.956 & 57.617 & 27.857 & 0,517 \\
1.958 & 64.667 & 28.271 & 0,571 \\
\hline
\end{tabular}

FONTE: PMU - Gabinete de Planejamento-1985

(1) Os anos que não aparecem são aqueles em que os número de lotes não se alterou.

De posse dos dados já analisados elaboramos a TABELA 02, que fornece o número de lotes na cidade de Uberlândia, ao longo dos anos de 1936/58, para cada grupo de 1.000 habitantes. A oferta relativa de terrenos, no período analisado, teve um 
crescimento de $67,4 \%$, passando de 261 terrenos/1000 habitantes em 1936 para 437 terrenos/1000 habitantes.
É interessante observar que a disponibilidade de lotes é muito elevada, atingindo valores ainda maiores no período,

\section{TABELA 02- UBERLÂNDIA: № DE LOTES EXISTENTES PARA CADA GRUPO DE 1.000 HABITANTES - 1936/58}

\begin{tabular}{lrrc}
\hline ANO & LOTES/1000 HAB. & ANO & LOTES/1000 HAB. \\
\hline 1.936 & 261 & 1.947 & 424 \\
1.937 & 255 & 1.951 & 340 \\
1.938 & 353 & 1.952 & 326 \\
1.939 & 345 & 1.953 & 502 \\
1.940 & 337 & 1.954 & 516 \\
1.943 & 276 & 1.955 & 504 \\
1.944 & 294 & 1.956 & 483 \\
1.945 & 424 & 1.958 & 437 \\
1.946 & 443 & - & - \\
\hline
\end{tabular}

FONTE: PMU: Gabinete de Planejamento - 1985.

como, por exemplo, em 1954, quando havia 516 terrenos/1000 habitantes. Se considerarmos famílias compostas por quatro indivíduos em média, iremos concluir que cada grupo de 1.000 pessoas constituirá 250 famílias, havendo, naquele ano, 516 terrenos, ou seja, mais de dois lotes por família, evidenciando claramente a intensidade do processo especulativo.

Essa prática vem se mantendo até os dias de hoje, pois muito pouco tem sido feito para deter esse processo de especulação imobiliária, que tanto onera aos cofres públicos, além de deteriorar a qualidade de vida na cidade, pelas grandes distâncias percorridas pelos seus moradores, carência de serviços urbanos e alto valor das terras.

Desde meados dos anos 30 os jornais já denunciavam esta situação, chamando a atenção para o número excessivo de terrenos vagos, tanto no centro, como nos bairros, criando dificuldades à administração pública no provimento de infra-estrutura urbana. Todavia, vale ressaltar que, segundo os jornais da época, contraditoriamente, a própria administração autorizava e incentivava a abertura de novos loteamentos.

Uma das dificuldades criadas à Prefeitura para a realização de muitos melhoramentos prende-se à ampliação excessiva da área da cidade, que possuindo menos de 40.000 habitantes, segundo o último recenseamento, ocupa dimensões para mais de 100.000. Por todos os lados, abremse vilas, por todos os lados, adquiremse terrenos, loteiam-se e são incorporados à zona urbana. (CORREIO DE UBERLÂNDIA, 29/11/51:01).

Segundo a legislação municipal vigente naquele período, os lotes deveriam ter no mínimo $300 \mathrm{~m} 2$, com áreas destinadas ao uso público, como as praças, comércios, 
sendo ainda proibida a abertura de ruas particulares. Entretanto, os loteamentos eram aprovados com todo o tipo de irregularidades, tais como áreas fora da malha urbana edificada, somente com arruamento, terrenos com $200 \mathrm{~m} 2$, ruas fechadas com construções residenciais ou empresariais. A citação abaixo retrata bem essa situação vivenciada na década de 50 :

\begin{abstract}
Nada de praças! É preciso vender todo o rico terreninho, mesmo que o lote não dê 300 m2 mínimos exigidos pela Lei Municipal. Antes de ser construída, Uberlândia já está sendo urbanisticamente condenada. [...] Os loteamentos também não se ligam com as plantas da cidade. E não tem a menor intenção de prestar atenção à nova planta que se está fazendo. Cada qual para seu lado (CORREIO DE UBERLÂNDIA, 21/01/53:01).
\end{abstract}

E assim foram crescendo os subúrbios, as chamadas vilas de Uberlândia, com adensamento de população, moradias e problemas de falta de água, energia elétrica, áreas de lazer, escolas e calçamento. Nesses lugares, a paisagem urbana em nada lembrava a Cidade Jardim, cantada em verso e prosa pelos administradores públicos, pelos empresários e jornalistas. Conseqüentemente, a cidade foi pensada e projetada historicamente, seguindo a lógica de mercado, princípio em que a exploração da terra urbana teria que ser a mais lucrativa possível, gerando vultosos recursos aos proprietários da terra, aos incorporadores imobiliários, enfim aos gestores do espaço urbano.

Essa era a prática corrente dos governantes, que sempre diziam, em seus discursos, que as condições de mercado regulariam e determinariam os resultados desse processo, sobretudo para aqueles cujos interesses econômicos se alinhavam aos políticos.
Uberlândia atravessa uma fase que não pode evitar a expansão de sua área. Ao mesmo tempo, em que se constróem os palacetes luxuosos, surgem as indústrias e cresce $O$ comércio. A primeira destas circunstâncias ocasiona a valorização dos terrenos centrais que só podem ser utilizados para grandes construções; a segunda exige a edificação de prédios modestos para os que se dedicam aos trabalhos correspondentes. Para conciliá-los, só estendendo os subúrbios, onde os lotes se vendem a preços módicos, reservando-se as avenidas e ruas principais para os projetos de valiosa arquitetura. (CORREIO DE UBERLÂNDIA, 05/08/44).

Durante muitos anos, as normas e diretrizes existentes relacionadas ao uso da terra urbana preocupavam-se apenas em ordenar o crescimento da cidade, no que diz respeito ao controle e tamanho das edificações no centro da cidade, ao alinhamento das casas e, em certa medida, ao seu uso e qualidade; entretanto, nunca foram tratadas questões referentes ao parcelamento do solo.

Os Códigos de Obras e Posturas de 1950 e 1970 de Uberlândia legislavam apenas quanto às questões de eugenia e higiene do espaço público, ao decoro urbano, ao controle e à observação de leis de trânsito e a algumas regras para a construção civil.

Desse modo, a organização espacial da cidade, principalmente de sua área central e seu estilo arquitetônico, refletiam apenas as necessidades e interesses dos incorporadores e de sua clientela, não sendo jamais levados em conta os interesses e benefícios da população em geral.

Portanto, a ausência de leis de uso e ocupação do solo urbano em Uberlândia, 
durante toda a sua história, incentivou a especulação imobiliária por parte dos proprietários de terra, incorporadores e gestores públicos.

Contudo, a elite uberlandense, mesmo tendo essa prática, teve a constante preocupação em construir uma imagem urbana que representasse o progresso, a modernidade.

Somente aquele que não têm olhos para enxergar os passos agigantados que tem dado na estrada luminosa do progresso e que, sem favor algum, nos coloca hoje num plano de excelência. Aí estão a corroborar com esta verdade, as construções que se têm feito ultimamente vazadas todas, sob os mais impecáveis traços da arquitetura moderna, imprimindo um aspecto de majestade $e$ graça às principais artérias de nossa urbe. (CORREIO DE UBERLÂNDIA, 14/03/44).

Essa elite, historicamente, manteve um discurso calcado nos parâmetros de ordem e progresso, estética e higiene, com intuito de viabilizar o desenvolvimento da cidade e a sua expansão econômica e, fundamentalmente, manter o seu controle e sua dominação.

De acordo com PECHAMN (1992:81) (...) foi a invenção da cidade do urbanismo, da paisagem, como conceitos referidos a realidade e práticas que permitiu a sua instauração como imagens reais e/ou imaginárias e, portanto, como campos de poder e dominação. Inventar a cidade, construir sua imagem e nomeá-la como temática são elos da cadeia de dominação que dão suporte à intervenção e legitimam a regulação e o controle.

A obsessão da elite local pelo progresso, mediado pela ordem e estética urbana, vem desde o início da ocupação do município, acirrando-se a partir dos anos 40 , quando a cidade é considerada um entreposto comercial.

A partir de então a cidade, com seus equipamentos, suas obras arquitetônicas, seu desenho urbano deveriam obedecer aos preceitos de modernidade, enfim de tudo aquilo que se traduzia na expansão das relações capitalistas. Para que isso acontecesse era preciso, segundo essa visão, acabar com a memória da cidade velha, carcomida; assim sendo, era inevitável a demolição de prédios antigos para dar lugar aos novos empreendimentos imobiliários, a remodelação e a conservação constante dos edifícios, a limpeza das ruas e praças, principalmente nas áreas mais centrais.

Essas eram algumas das estratégias do poder local, no que diz respeito à erradicação de tudo aquilo que se identificava com o arcaico, antigo, atrasado e tradicional.

Analisando essa necessidade das elites quanto à reformulação das cidades, CAVALCANTI (1987:96) observa que, grosso modo, a mudança sendo identificada com a construção do "novo", o avanço nesta direção reproduziria uma concepção dualista em que o atraso e o tradicional se incompatibilizariam com o moderno. Ser moderno, portanto, implicaria a identificação com estes traços novos portadores de progresso e, consequentemente, da superação do atraso.

Os argumentos da elite local, no que diz respeito ao progresso, ordem e beleza, deveriam ser expressos no espaço urbano, pois sua constante necessidade de embelezar e ordenar a cidade veio de encontro às mudanças relacionadas à expansão das relações capitalistas que impuseram novos conteúdos à sociedade. 
Segundo PECHAMN (1993:78), a identificação da dualidade atrasado $X$ moderno serve, portanto, de base para a criação de uma nova concepção de sociedade e para uma nova visão de cidade, numa economia que transita para o capitalismo. Trata-se da adoção de novos valores que exigem uma nova urbanidade, impondo aos atores dessa nova cidade, novas atitudes e novos comportamentos.

De acordo com essa filosofia, era necessário ordenar a paisagem da cidade, impondo regras para manter a limpeza dos espaços públicos, uma vez que os mesmos eram, por excelência, os lugares de encontro e passagem e, portanto, deveriam ser a expressão dos padrões higiênicos e estéticos. Com relação aos espaços privados degradados, a ordem era a remoção de tudo aquilo que relembrasse um tempo que se queria esquecer.

\section{A própria avenida Afonso Pena se é verdade que está toda ocupada é também exato que conta com casebres condenados numa via dessa natureza e que precisam desaparecer para a honra do nosso urbanismo. \\ (CORREIO \\ UBERLÂNDIA, 06.06.45:01).}

Quanto aos bairros periféricos, os mesmos deveriam ser saneados ou, pelo menos, ficar escondidos à vista dos visitantes, pois ali só existia a baderna, o barulho e a sujeira.

Tabocas é um lugar marcado. Além da pobreza que impera em Tabocas, a vadiagem fez lá o seu reino. Homens fortes tocam viola o dia inteiro; enquanto mulheres magras, macilentas mendigam tostões que eles mesmo vão gastar em farras e cachaçadas ao rebolar dos sambas no chão batido.[...] É assim a cidade dos párias, favela uberlandense em franco e crescente movimento. (CORREIO

DE UBERLÂNDIA, 21/07/55:01).

Enfim, era preciso eliminar das áreas públicas os sinais de desordem, impondo uma nova conduta que levasse à construção de um espaço limpo, belo e saudável e, que, conseqüentemente, colocasse a cidade na rota do progresso, este sim, a eterna busca da elite uberlandense.

MARTINS (1992:36), quando analisa São Caetano do Sul - SP, mostra-nos a relação entre ordem/trabalho/progresso das elites.

A noção de ordem das elites estava, portanto, centrada na concepção de que a ordem resulta do trabalho e de que em relação ao pobre, só é trabalho o trabalho agrícola; tudo mais é vadiagem. [...] A ordem só era possível num espaço ordenado, circundado e vigiado. No imaginário das elites, a ordem e seu espaço não se separavam.

Isto era exatamente o que a elite uberlandense reforçava através da imprensa: seu discurso em relação ao ordenamento da cidade, à necessidade de manutenção do trabalho, da ordem, para sua perpetuação no poder. $E$, sendo assim, a construção da imagem de cidade moderna e progressista era seu principal objetivo.

\section{CONSIDERAÇÕES FINAIS}

A construção de uma cidade cuja imagem expressasse o progresso e a modernidade foi possibilitada, principalmente, a partir dos anos 50, quando Uberlândia passou por enormes transformações em seu conteúdo e forma urbana, em decorrência direta da implantação de estradas de rodagem que interligavam o Centro Oeste ao Centro Sul brasileiro e à construção de Brasília, para a qual Uberlândia serviu de entreposto, fornecendo de mão-de-obra para 
a construção civil. Além disso, beneficiou-se muito das políticas de interiorização do país, propostas pelo Governo Juscelino Kubtischek de Oliveira. A nivel local, as elites implantaram projetos políticos que consolidassem a cidade no contexto regional.

Desse modo, entre os anos 50 e 80, o espaço urbano de Uberlândia passa por transformações econômicas, sociais e culturais nunca antes vivenciadas por sua população. No que diz respeito à sua forma urbana, fruto do desenvolvimento das relações sócio/espaciais, as mudanças foram significativas, pois foram criados os loteamentos nobres, os arranha-céus, os conjuntos habitacionais, o asfalto, o neon, a televisão, o supermercado, o Distrito Industrial, a Universidade Federal, e os shopping-centers, entre outros.

Tendo em vista o crescimento populacional e econômico decorrente dessas transformações, intensificaram-se também as contradições nas formas de ocupação do solo urbano, tais como: expansão dos subúrbios, densificação do núcleo central e problemas de tráfego e transporte.

\section{BIBLIOGRAFIA}

BRANDÃO, C. Triângulo: Capital comercial, geopolítica e agroindústria. Dissertação de Mestrado. Belo Horizonte: CEDEPLAR/UFMG, 1989.

BAUDRILLARD, J. A sociedade de consumo. Lisboa: Edições 70, 1981.

BEAUJEU-GARNIER, J. Geografia Urbana. Lisboa: FCG, 1983.

CAETANO, C. G.; DIB, M. M. A UFU no imaginário social. Uberlândia: EDUFU, 1988.

CAVALCANTE, B. Beleza, limpeza, ordem e progresso: a questão da higiene na cidade do Rio de Janeiro no final do século XIX. Revista Rio de Janeiro. Niterói: EDUFF, ano 1, no 01, p. 95-104, 1987.

CHIAVARI, M; CARVALHO, V. Morar no centro da cidade do Rio de Janeiro. In: SÁ, M. (org.). Olhar urbano, olhar humano. São Paulo: IBRASA, 1991.

CORRÊA, R. L. Rede Urbana. São Paulo: Ática, 1989. (Coleção Princípios).

DEL GROSSI, S. R. De Uberabinha a Uberlândia: os caminhos da natureza. São Paulo: FFLCH/USP, 1991. (Tese, Doutoramento).

FERRARA, L. D. Ver a cidade. São Paulo: Nobel, 1988.

GOMES, R. Todas as cidade, a cidade. Rio de Janeiro: Rocco, 1994.

GUIMARÃES, E. N. Infraestrutura pública e movimentos de capitais, a inserção do Triângulo Mineiro na divisão interregional do trabalho. Belo Horizonte: CEDEPLAR/ UFMG, 1990. (Dissertação, Mestrado).

LEFEBVRE, H. La revolucion urbana. Madrid: Alianza, 1983.

MARTINS, J. S. Subúrbio - Vida cotidiana e história do subúrbio da cidade de São Paulo - São Caetano do fim do Império ao fim da República. São Paulo: HUCITEC, 1992.

MARX, M. Cidade Brasileira. São Paulo: EDUSP, 1993.

PLANO de Urbanização de Uberlândia. Belo Horizonte: IHG, 1954.

PECHMAN, R. M. (Org.). Olhares sobre a cidade. Rio de Janeiro: EDUFRJ, 1994.

Um olhar sobre a cidade: estudo da imagem e do imaginário do Rio na 
formação da modernidade. Cadernos do IPPUR. Rio de Janeiro: UFRJ/IPPUR, no 01, p. 77-89, dez. 1992.

PINTAUDI, S. O lugar do supermercado na economia capitalista. Geografia. Rio Claro: UNESP, 1988.

RELPH, E. A paisagem urbana moderna. Lisboa: Edições 70, 1987.

REIS FILHO, N. A perspectiva do arquiteto sobre a cidade. In: PECHAMN, R. M. Olhares sobre a cidade. Rio de Janeiro: EDUFRJ, 1994. p. 169-180.

SANTOS, M. Por uma economia política da cidade. São Paulo: HUCITEC, 1994.

SITTE, C. A construção das cidades segundo seus princípios artísticos. São Paulo: Ática, 1993.

SOARES, B. R. Uberlândia: da "Cidade Jardim" ao "Portal do Cerrado": imagens e representações no Triângulo Mineiro. São Paulo: FFLCH/USP, 1995. (Tese, Doutorado).

SOARES,B. R; RAMIRES, J. L. As transformações do centro de Uberlândia no contexto da expansão da cidade. Sociedade \& Natureza. Uberlândia: EDUFU, ano 5, no 09-10, p. 39-48, 1993.

SODRÉ, M. A máquina do narciso. São Paulo: Cortez, 1990.

SOUZA, M. A. A identidade da metrópole e a verticalização em São Paulo. São Paulo: FFLCH/USP, 1989. (Livre Docência).

SPOSITO, M. E. O centro e as formas de expressão da centralidade urbana. Revista de Geografia. Presidente Prudente: UNESP, no 10, p. 01-18, 1991.
JORNAIS E REVISTAS

O REPORTER - Várias Edições

CORREIO DE UBERLÂNDIA - Várias Edições

REVISTA ELITE MAGAZINE - Várias Edições

UBERLÂNDIA ILUSTRADA - Várias Edições

ÁLBUM DO TRIÂNGULO MINEIRO - Várias Edições. 